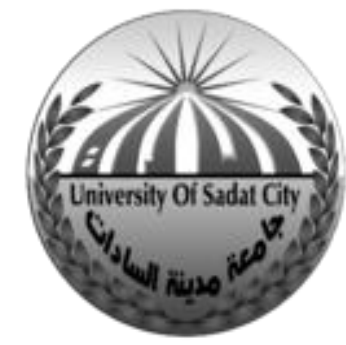

جامعة مدينة السادات كلية التربية

قسم التربية

متطلبات تنمية الإبداع الإداري لدى مديري المدارس الثانوية العامة بجمهورية مصر العربية في ضوء مدخل إدارة التغيير

مستخلص بحث مقدم استكمالاً لمتطلبات الحصول على درجة الدكتوراه فى التربية

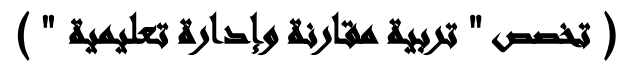

\author{
العسات الملامهي \\ أسامة محمد أحمد عبد العال
}

إشراف

أ.د /زهير السعيد همازي

أستاذ أصول التربية المتفرغ

كلية التربية - جامعة مدينة|لسادات المول لتربه
أ.د / هصطفى هممد رجب أستاذ أصول التربية المتفرغ

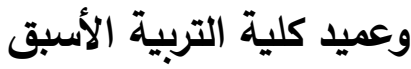
جامعة سوهاج 
إن الإبداع الإداري من الموضوعات المهمة التي بدأت تستحوذ على اهتمام علماء الإدارة في الوقت

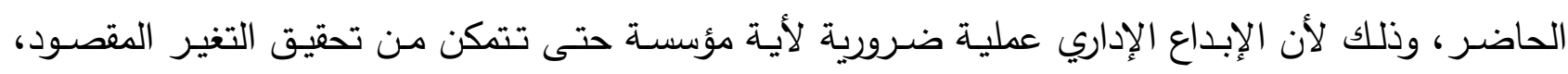

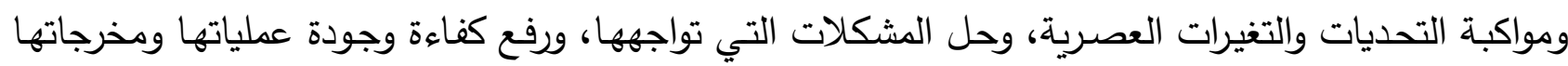
المختلفة.

كما أن مدير المدرسة التقليدي بات عبئا ثقيلا على مؤسسته التربوية، معطلا للعملية التربوية لا مسيراً

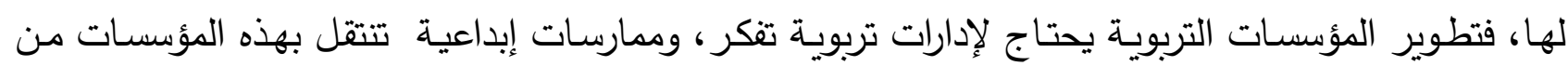

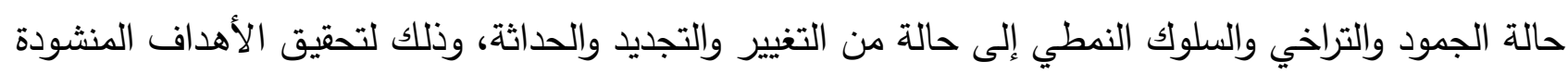

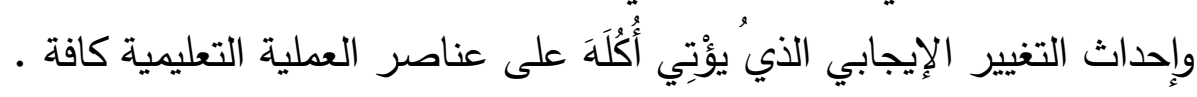
ولذا يحتـاج تطوير المـارس الثانويـة إلى قـادة تغييـر داخل مدارسـهم متسـلحين بالأفكـار الإبداعيـة

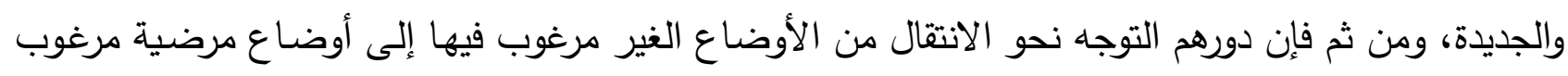

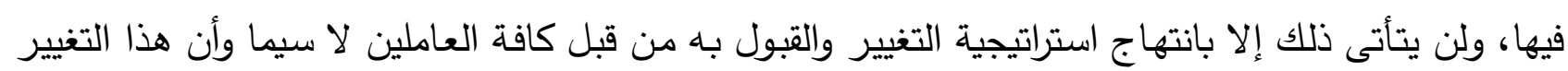
يؤدي إلى تطوير الأداء وزيادة إنتاجية وكفاءة المدارس الثانوية.

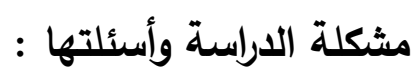
تؤكد العديد من الأدبيات أن التعليم يتأثر إلى حد كبير بقدر ما يحدثه مدير المدرسة من تطور في أداء

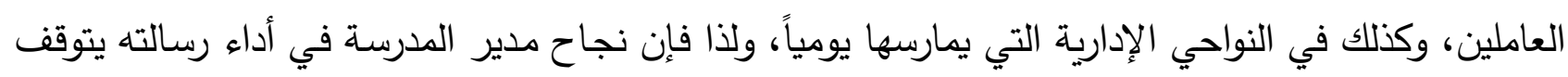

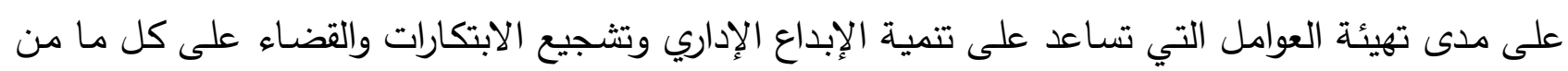
شأنه أن يعيق الإبداع بأي شكل من الأشكال.

ومن ثم يجب أن تنطلق الجهود سواءً أكانت من الأفراد أم المنظمات العامة والخاصـة لتتمية مهارات

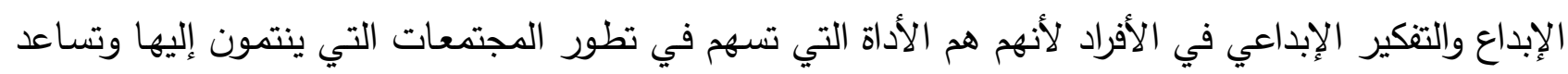

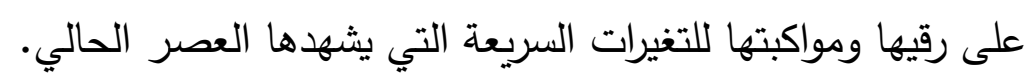

ولقد استتبط الباحث، من خلال عمله في التعليم الثانوي، ومن خلال إطلاعه على بعض الدراسات السابقة أن هناك قصورا في الأداء لاى مديري الددارس الثانوية في جمهورية مصر العربية، الأمر الذي يتطئل

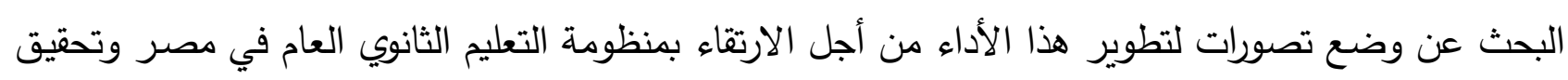
أهدافه المنشودة. 
وفي ضوء مشكلة الدراسة الحالية يمكن تحديد أسئلة الدراسة في السؤال الرئيس التالي:كيف يمكن تنمية الإبداع الإداري لاى مديري المدارس الثانوية العامة في ضوء إدارة التغيير؟ ويتفرع عن هذا السؤال الرئيس مجموعه من الأسئلة الفرعية التالية : 1- ما مستوى توفر مهارات الإبداع الإداري لاى مديري المدارس الثانوية العامة في محافظة سوهاج من وجهة نظر أفراد العينة ؟ بونة ץ- ما درجة ممارسة مديري المدارس الثانوية العامة في محافظة سوهاج لإدارة التغيير من وجهة نظر أفراد

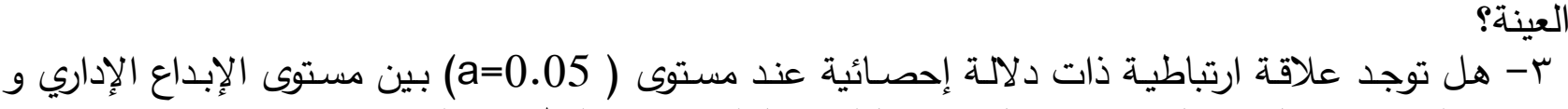

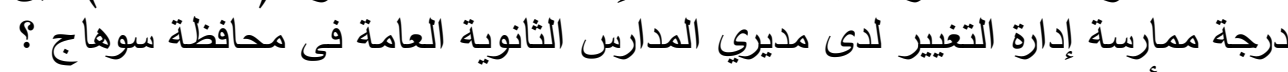

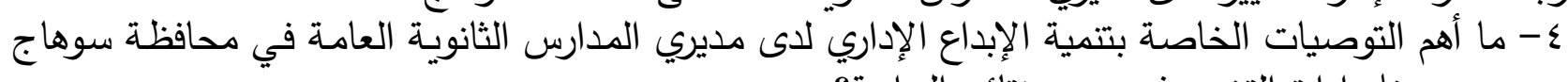

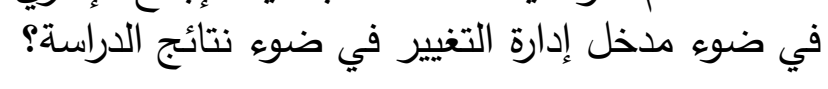
أهداف الدراسة :

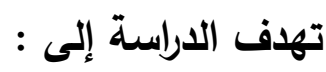

1- التعرف إلى مستى لـى توفر مهارات الإبداع الإداري للى مديري المـارس الثانويـة العامـة بمحافظـة

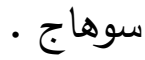
r- التعرف إلى درجة ممارسة مديري المدارس الثانوية العامة بمحافظة سوهاج لأساليب إدارة التغيير.

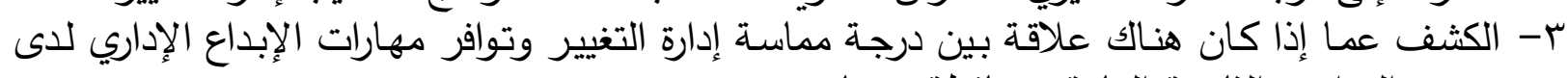

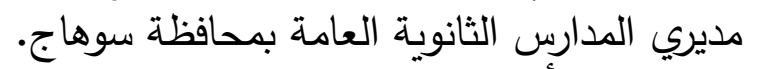

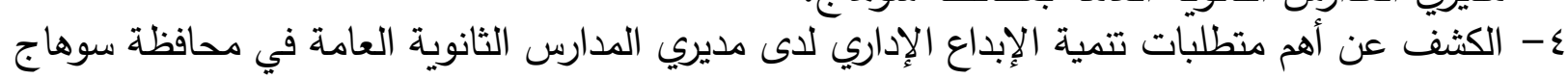

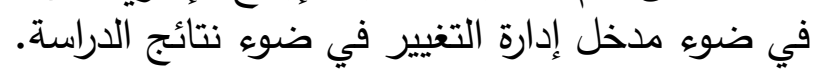

\section{أهمية الاراسة}

قد تسهم الدراسة في تعرف أو الكثف عن المهارات الإبداعية اللازمة لمديري المدارس الثانوية العامة

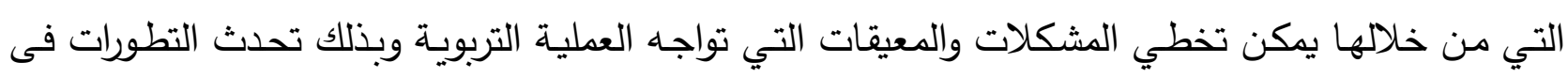
حدود الدراسة التزبوي.

تقتصر الدراسة على وضـع تصور مقترح لتتمية الإبداع الإداري للدى مديري الددارس الثانويـة العامة بمحافظة سوهاج في ضوء مدخل إدارة التغيير. منهج الدراسة وأدواتها: يعتمد البحث علي المنهج الوصفي لملائمته لطبيعة الموضوع حيث إن هدفه لا يتوقف عند وصف الظاهرة

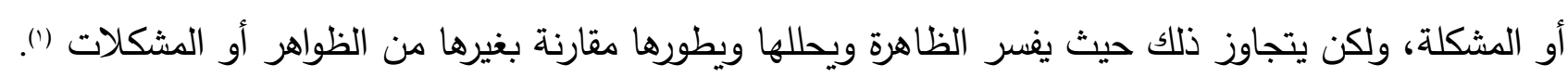
كما تم استخدام الاستبانة لجمع وتحليل البيانات.

' - على السيد الثخيبي ، علم اجتماع التربية المعاصر، تطوره ومنهجيته، تكافؤ الفرص التعليمية، سلسلة المر اجع فى التربية

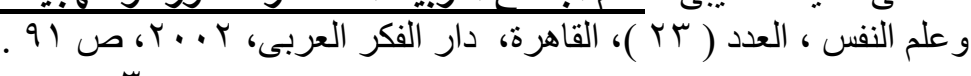




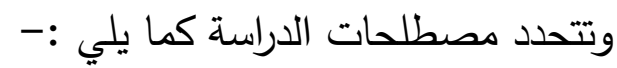

1- الإبداع الإداري:

استخدام مدير المدرسة لخبراته ومعارفه وما لديه من إمكانات لتقديم أفكار جديدة وأساليب عمل متميزة

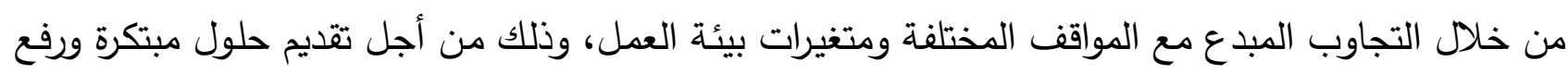

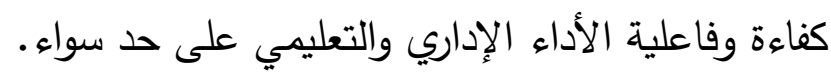

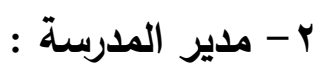

يعتبر المدير السلطة التنفيذية في مدرسته في نطاق اختصاصاته(')، وهو الرئيس التنفيذي المسئول عن

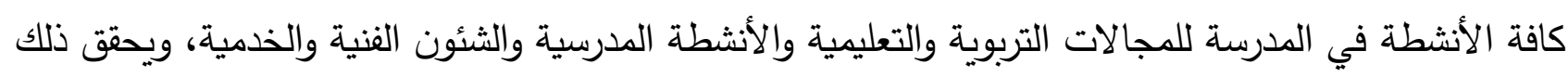

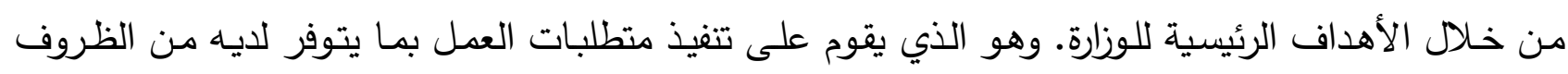

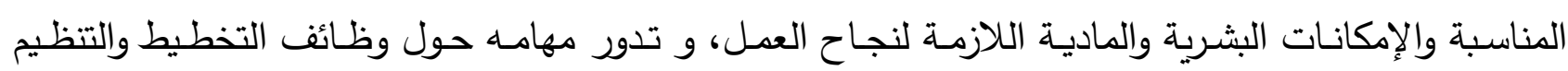
والتوجيه والرقابة بغرض تحقيق أهداف المنظمة. ب- إدارة التغيير: انتقال الإدارة المدرسية من الأوضاع الحالية إلى الأوضاع الجديدة المرغوب فيها داخل المدرسة والتي من شأنها تحقيق أعلى درجة من الكفاءة والفاعلية .

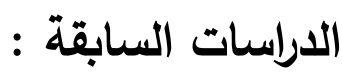

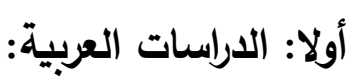
1- الاحتياجات التدريبية لتنمية الإبداع الإداري لادى القيادات المدرسية بالحلقة الثانية من التعليم الأساسي

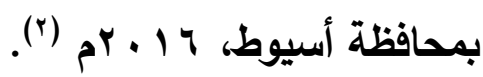

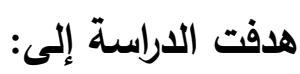

$$
\text { ا - تعرف الأسس الفكرية والنظرية لتتمية الإبداع الإداري لدى القيادات المدرسية. }
$$

r- الكثف عن العلاقة بين الاحتياجات التدربية وأبعاد الإبداع الإداري للقيادات المدرسية بالمرحلة الثانية

$$
\text { من التعليم الأساسي بمحافظة أسيوط. }
$$

واستخدم الباحث أسلوب دراسـة الحالة لمسح وتحليل الأدب الدتعلق بموضوع الدراسة، واستخدم الاستبانة

$$
\text { لجمع البيانات (موجهة للقيادات المدرسية). }
$$

' ـ طارق عبد الحميد البدري ، الاتجاهات الحديثة للإدارة المدرسية في تنمية القيادة التدريسية،عمان ، دار الثقافة، ه . بrم، ص س

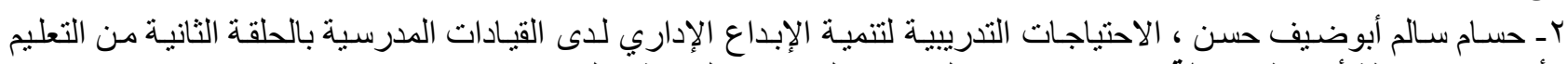

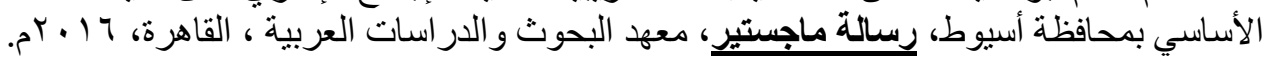




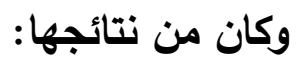

- كثرة أبعاد الإبداع الإداري للقيادات المدرسية، ومن أبرزها الريادة، المثابرة، المبادرة، الإلهام.

- ق قلة احتواء العملية التدريبية في محافظة أسيوط على برامج تنمي الإبداع الإداري للقيادات الددرسية

بالحلقة الثانية من التعليم الأساسي.

r - تطوير إدارة الجامعات الناشئة بالمملكة العربية السعودية في ضوء مدخل إدارة التغيير"تصور مقترح"،

(1).

هدفت الدراسة إلى :

- - تحديد المفاهيم الأساسية لإدارة التغيير بالتعليم الجامعي.

- تعرف واقع إدارة الجامعات الناشئة في ضوء مدخل إدارة التغيير •

- التوصل لتصور مقترح لتطوير إدارة الجامعات الناشئة بالمملكة العربية السعودية في ضوء مدخل

إدارة التغيير.

واستخدمت الاراسة المنهج الوصفي لتحقق أهدافها، وتجيب عن تساؤلاتها، من حيث تعرف واقع إدارة

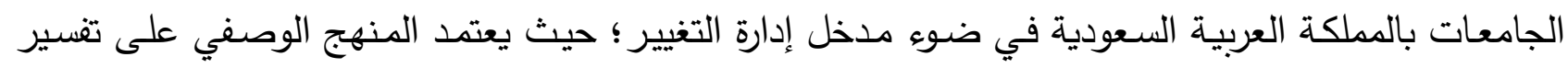

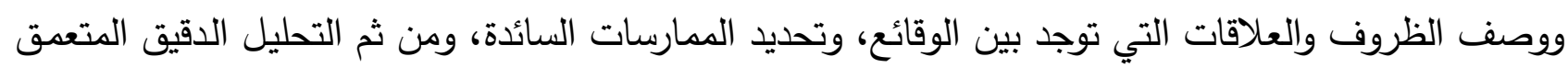

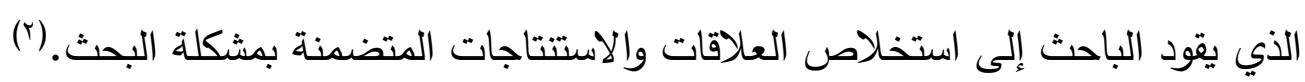
وكان من نتائج الداسة:

$$
\text { ו- لا توجد فروق ذات دلالة إحصائية تعزي لمتغير الجامعة(طيبة/الجوف/تبوك). }
$$

r- هناك فروق ذات دلالمة إحصائية تبعًا لمتغير الرتبة الأكاديمية. وهي جميعًا لصـالح رتبة أستاذ

$$
\text { مساعد. }
$$

r- هناك فروق في جميع المحاور ذات دلالة إحصائية تبعًا لمتغير نوع العمل لصالح العمل الإداري

$$
\text { والتدريسي معًا. }
$$

' - صالح أحمد عايد البلوي، تطوير إدارة الجامعات الناشئة بالمملكة العربية السعودية في ضوء مدخل إدارة التغيير "تصور مقترح"،

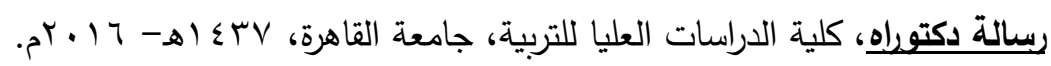

2 - Lodico, M. \& et al: Methods in Educational Research; From Theory to practice, JosseyBass, London, 2006, p104. 
ب- تطوير الممارسـات الإداريـة لمديري المـارس الثانويـة العامـة بمصر على ضـوء مدخل الإدارة بـالقيم، (').

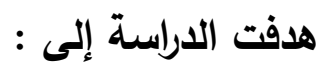
1- تعرف الممارسات الإدارية لمديري المدارس الثانوية العامة. r- تعرف واقع الممارسات الإدارية لمديري الددارس الثانوية على ضوء الإدارة بالقيم من وجهة نظر معلمي

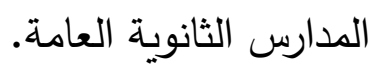

ب- تقديم تصـور مقترح لتطوير الممارسـات الإداريـة لمديري المدارس الثانويـة على ضـوء نظريـة الإدارة بالقيم.

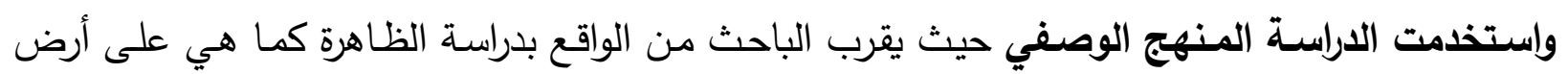

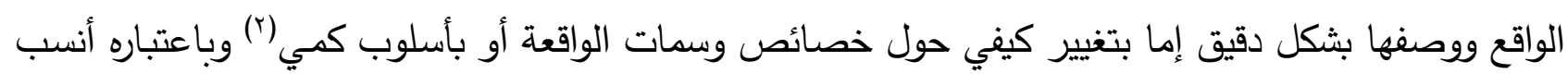

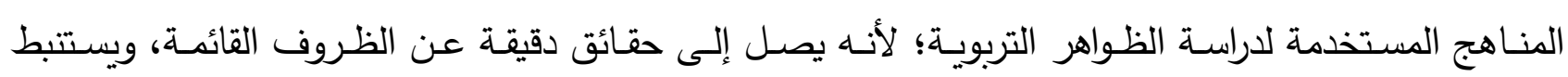

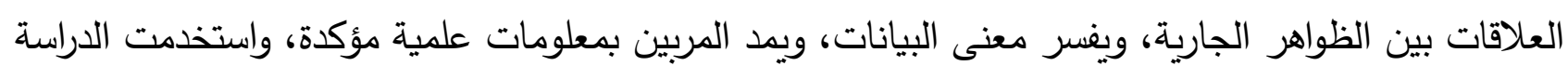

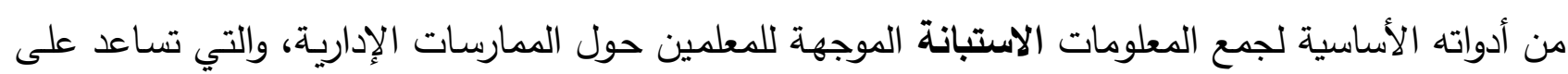

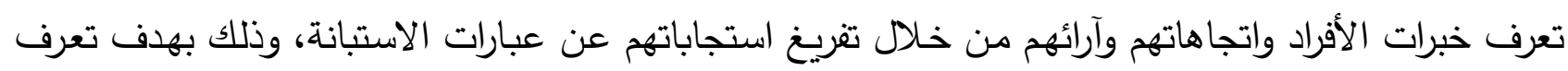

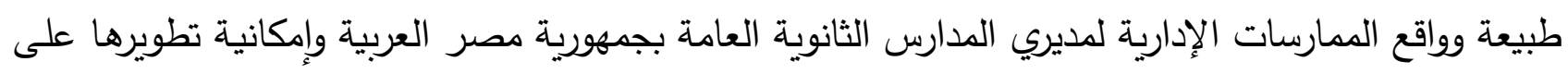

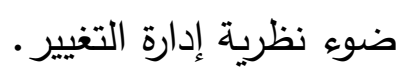
وكان من نتائج الدراسة: إنغير 1- ندرة الاهتمام بعملية التدريب المستمر والمنظم والمعد على أسس علمية حديثة. r- ندرة الاهتمام بالتطوير الذاتي لمدير الددرسة الثانوية. r- ندرة تثجيع مدير الددرسة للعاملين داخل الدرسة على الابتكار والإبداع. ثانياً : الدراسات الأجنبية:

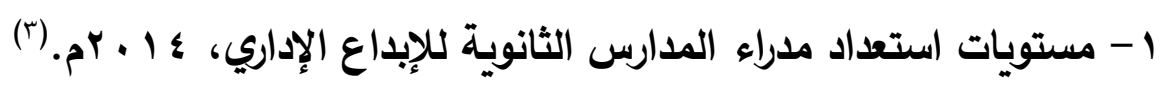

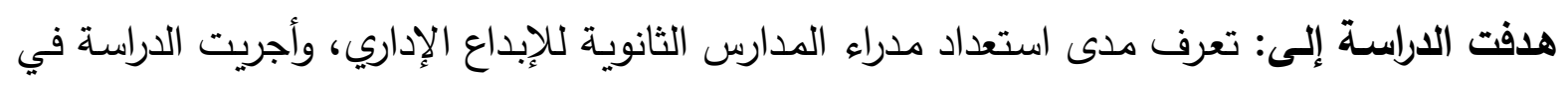

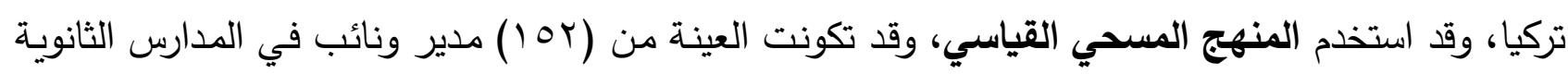

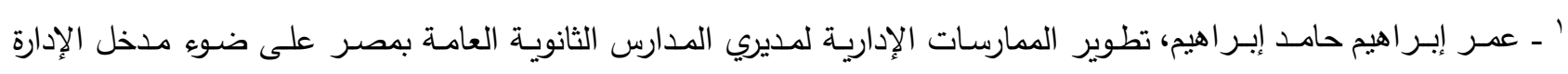

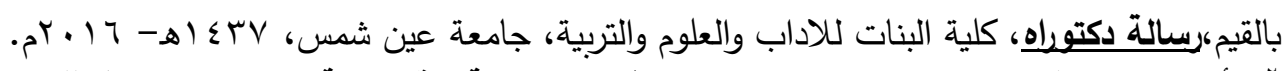

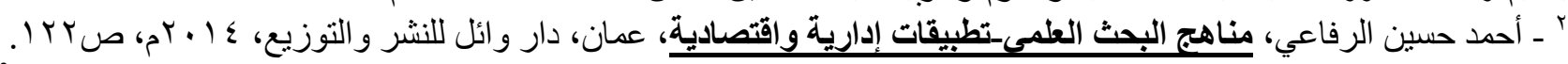
3 - Gilsen, C., The readiness levels of secondary school administrators to the innovation management, International Journal on New Trends in Education and Their Implications, Vol.5, No.2, 2014. 


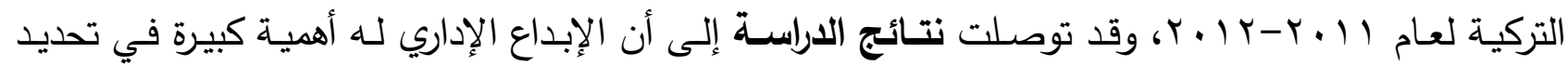
مستقبل المؤسسات التعليمية، وأكدت الدراسة أن مدراء الددارس كانوا على استعداد تام لتنفيذ الإبداع الإداري.

r- العلاقة بين القيادة المشتركة والإبداع الإداري في المدارس الكويتية، 17 ـ بم. (') هدفت هذه الدراسة إلى: استكثاف العلاقة بين القيادة المشتركة والإبداع الإداري في المدارس. الإست أجريت

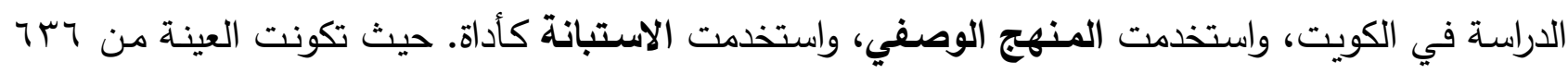

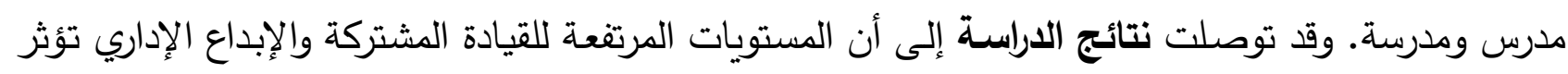

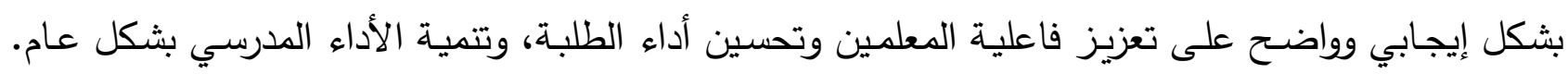
وذلك لأن المستويات الإبداعية للإدارة تسهل تتفيذ العمليات التعليمية بثكل أسهل وأدق وأكثر فاعلية. وبعد أن تتاول الباحث الإطار العام للدراسة من حيث المقدمة ومشكلة الدراسة وأسئلتها وأهدافها

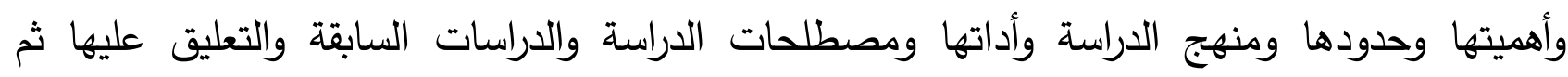
خطوات الدراسة، سوف يتتاول الباحث محاور الدراسة.

\section{المحور الأول: الأطر النظرية والفكرية للإبداع الإداري}

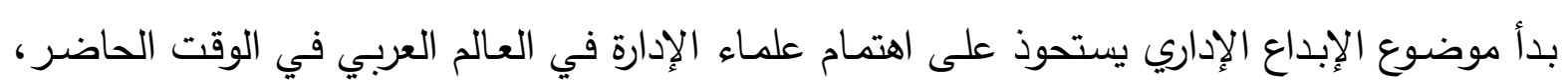

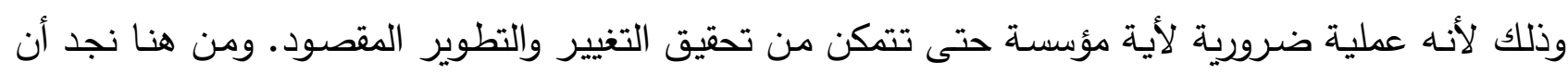

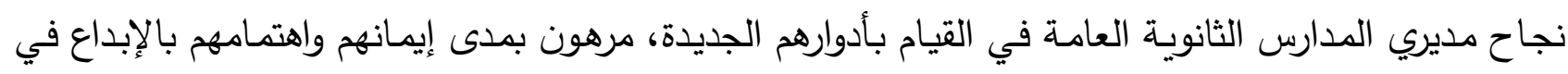
العمل الإداري.

\section{أهمية الإبداع الإداري لإى مديري المدارس الثانوية:}

يعد الإبداع الإداري من المقومات الأساسية في عملية التغيير، وتتجلى أهمية الإبداع عند ظهور

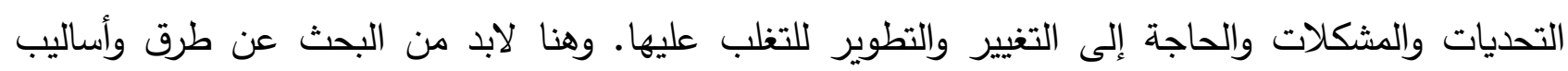
جديدة ومختلفة لحل المشاكل وتحسين الأداء وتحقيق الأهداف.

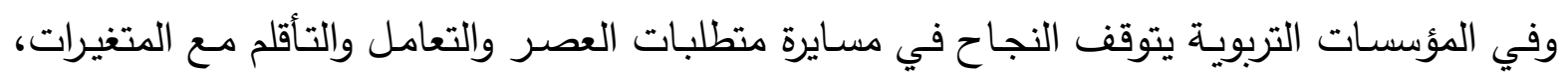

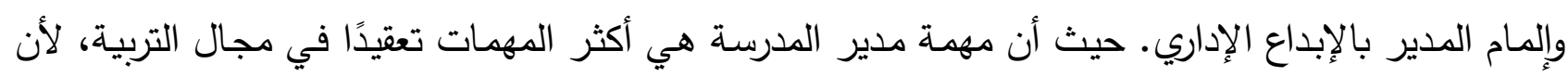

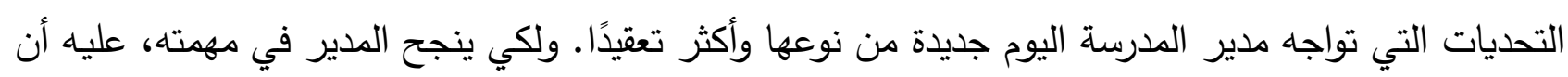

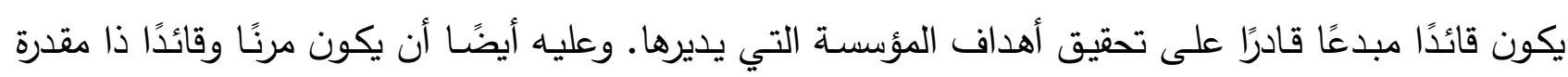

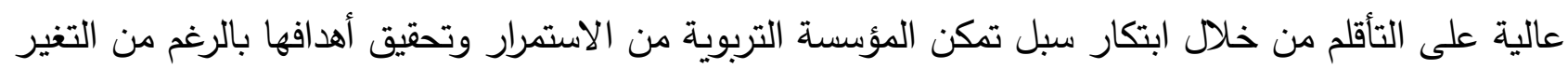

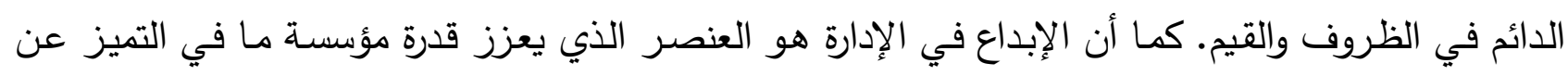


غيرها وبالتالي الصمود أمام المنافسة، وبالتالي قدرتها على الاستمرار والازدهار ، إذ يعد الإبداع من أهم العوامل التي تضفي على المؤسسات التربوية أهمية في ضوء المنافسة التي اشتدت بينها للبقاء والتقوق (').

وتكمن أهمية الإبداع الإداري في تطوير وتتمية قدرات مديري المدارس وتمكينهم من توفير بيئة تعليمية

مناسبة، فهو يشكل حافزًا لكل من مديري المدارس والمعلمين، ويساهم الإبداع الإداري وممارساته مثل المرونة

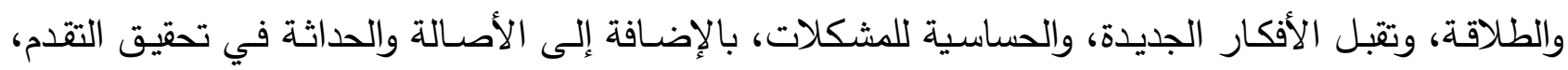
فالتقدم لا يصنعه سوى المبدعون (r).

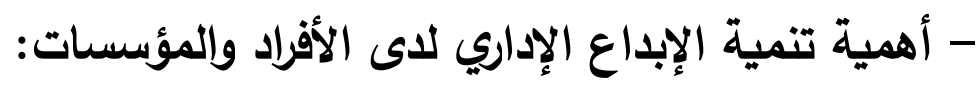
إن التطورات المحيطة بنا والناتجة عن ثورة المعلومات والانفجار التكنولوجي، وزيادة حدة المنافسـة بين الثـركات والمؤسسـات، وتتوع حاجـات الأفراد وزيـادة طموحهم وقلة المـوارد، وزيـادة

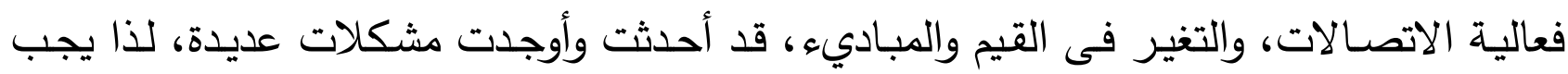

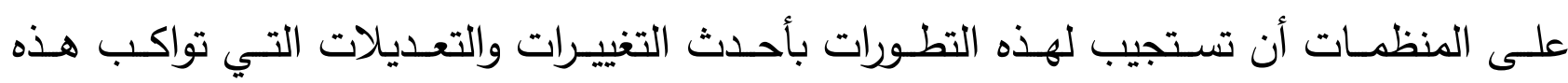
التطورات، ولا يمكن تحقيق ذلك إلا بوجود الأفكار الجديدة والأساليب الحديثة التي تستجيب لهذه التغييرات المستمرة.

\section{ومن ثم أصبحت تنمية الإبداع الإداري ضرورة لعدة أسباب، منها:}

1- المبدعين هم صانعوا الحضارة المادية والروحية. r- تتمية الإبداع ورعاية الموهوبين ضرورة ملحة لكل أمة ترغب فى التقدم والازدهار . r- المبدعين هم الثروة الحقيقية للأمة والوطن عند رعايتهم واستثمار إبداعاتهم. ع - الدول الأقوى هي التي تملك عدداً أكبر من المبدعين في مجالات الحياة المختلفة (؟). عناصر الإبداع الإداري لأى مديري المدارس الثانوية:

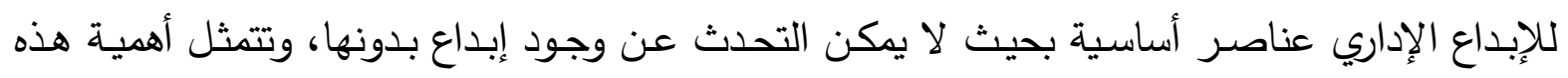

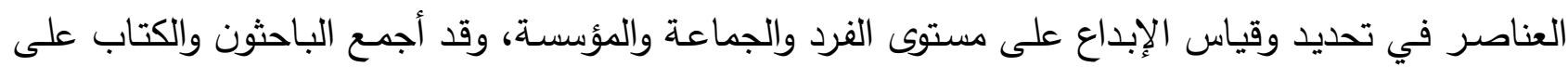

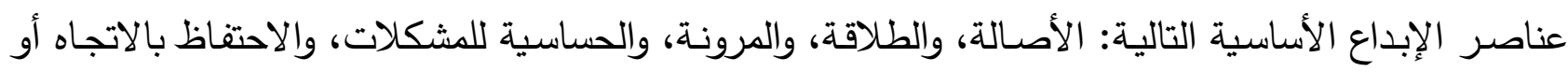

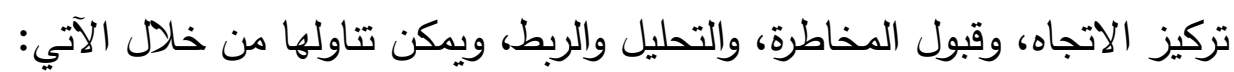

1 - Brogmenke, A., Avoiding the change trap: Strategies for school leaders in times of change. Texas: National Forum of Educational Administration and Supervision Journal, Vol.29, No.2, 2012 , p.12.

2 - Soleimani, N., \& Tebyanian, E., A study of the relationship between principal's creativity and degree of environmental happiness in Semnan high schools, Procedia - Social and behavioral Sciences 29, 2011, P-P 1869-1876.

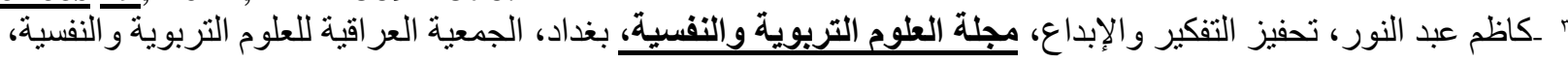


1- الأصالة Originality: وهي القدرة على الإتيان بالأفكار الجديدة النادرة والمفيدة وغير المرتبطة بتكرار

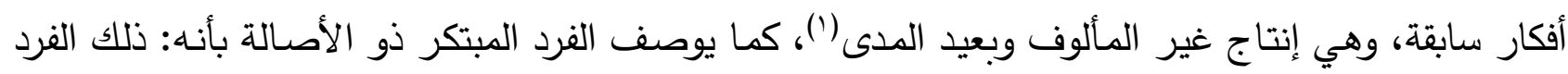
الذي يستطيع أن يبتعد عن المألوف أو الثائع، وبالتالي يدرك العلاقات ويفكر في أفكار وحلول مختلفة عن تلكاتك

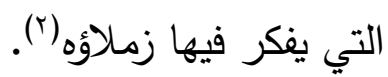
ץ- الطلاقـة Fluency: وهي القدرة على استدعاء أكبر عدد مدكن مـن الأفكار أو البدائل أو التوجهات

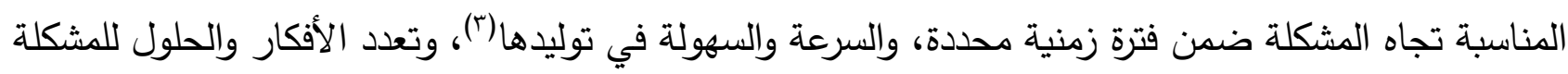

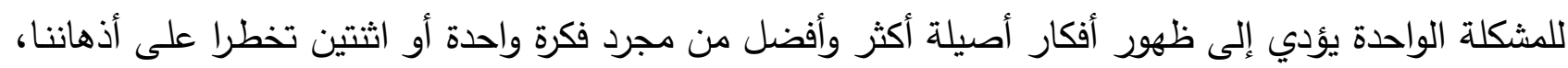

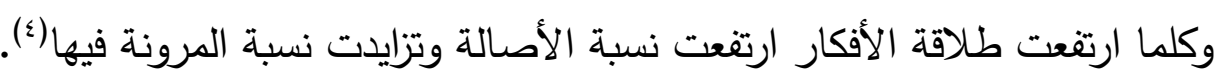
ץ- المرونة Flexibility: هي القدرة على التكيف مع التغيرات والتحرر من جمود الفكر والتحول إلى التلقائية

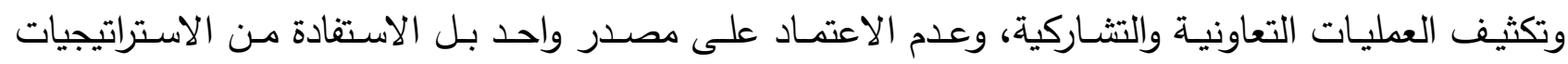

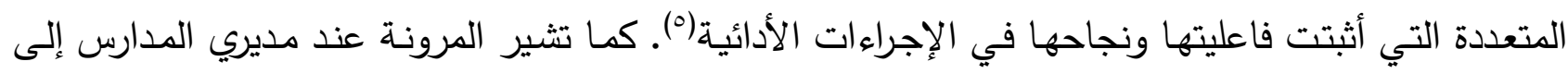

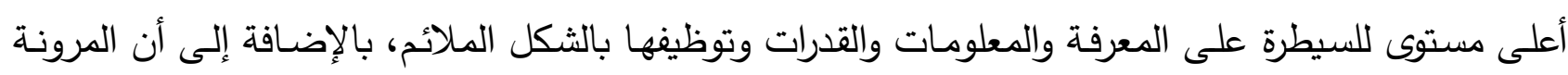

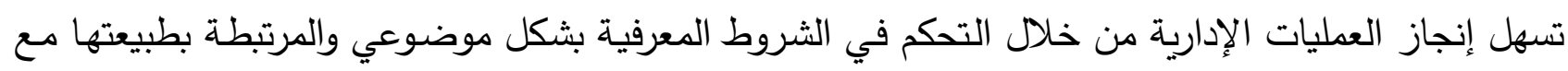

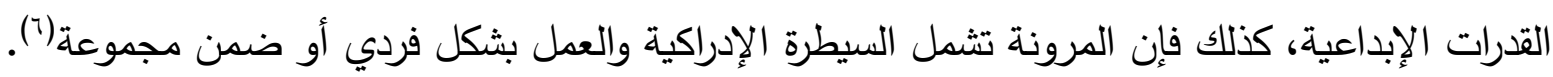

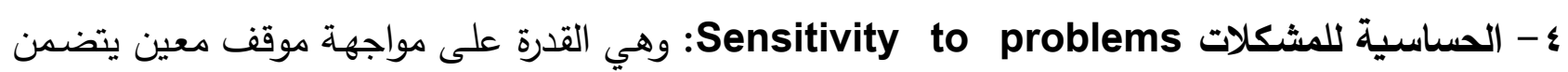

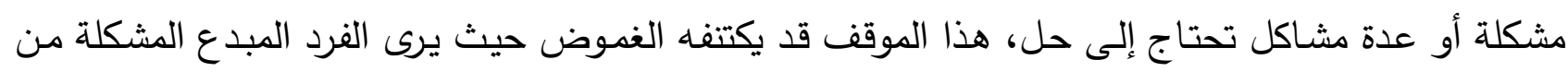

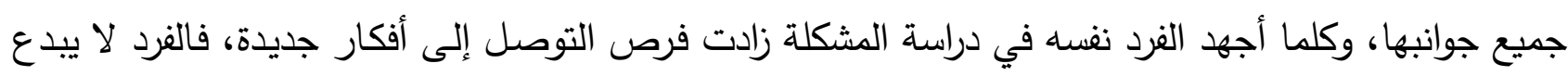

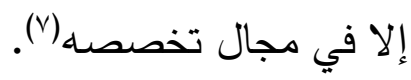
ه - الاحتفاظ بالاتجاه ومواصلتهMaintenance of Direction: وتتمثل هذه القدرة في استمرارية تفكير

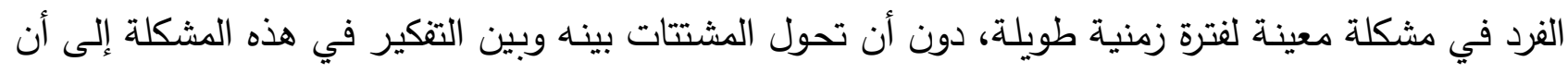

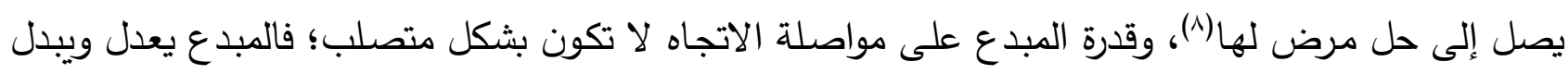

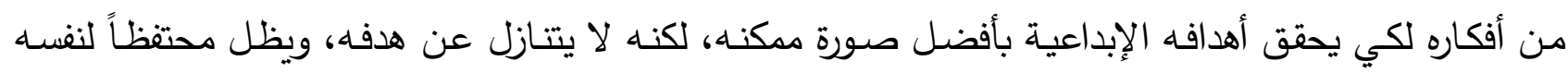

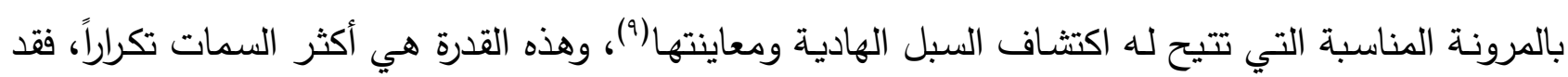

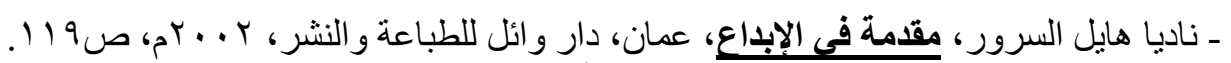

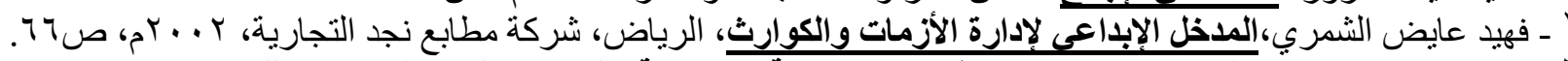

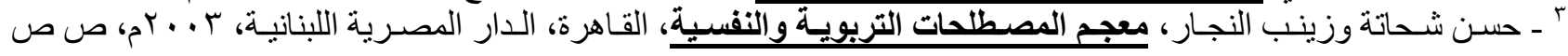
rYV.riA

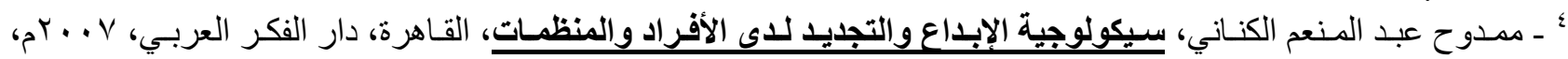
5 - Al-Oweidi, A., Creative Characteristics and its Realism to Achievement and School Type among Jordanian Students, Creative Education, Vol.4, No.1, 2013, P.39.

${ }^{6}$ - Zabelina, D \& Robinson, M., Creativity as Flexible Cognitive Control, Psychology of Aesthetics, Creativity, and the Arts, Vol.4, No.3, 2010, p.137.

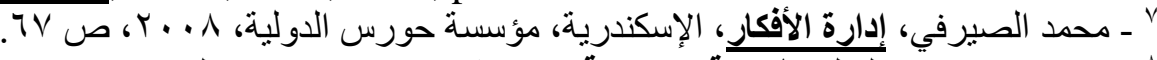

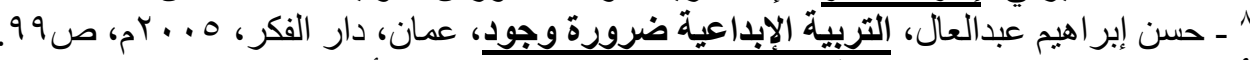

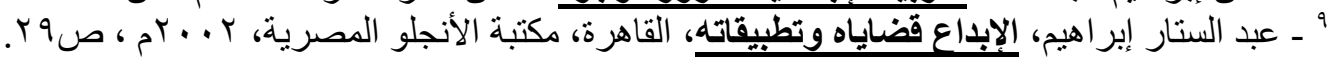


يواجه الباحث أثناء بحثه صعوبات مفاجئة، فإذا لم يكن يتمتع بهذه القدرة فقد يستبد بـه اليأس ويتوقف عن

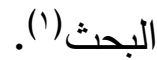
צ- قبول المخاطرة Risk-Taking: وهي تعبر عن مدى شجاعة الفرد في تعريض نفسه للفشل أو النقد

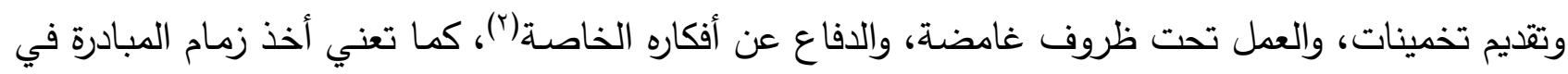

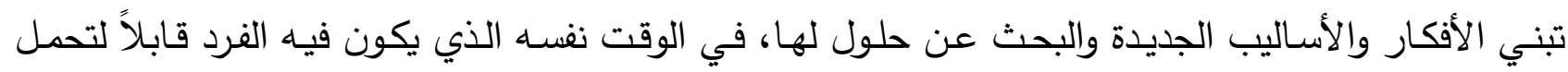

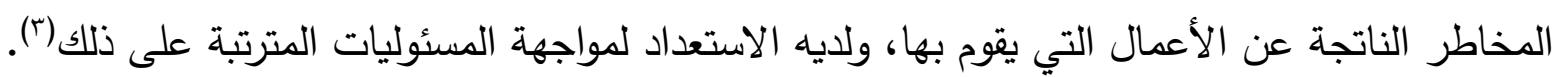
- V التحليل (Analysis)، والربط (Synthesis): أ- التحليل: هو القدرة على تحليل المركبات إلى عناصرها الأولية، وعزل هذه العناصر عن بعضها البعض،

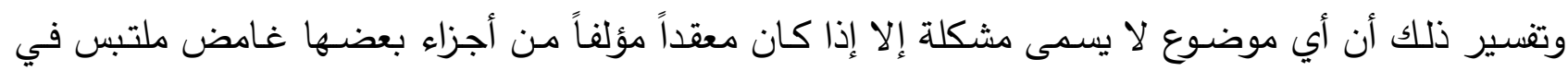
البعض الآخر ، وأول ما ينبغي عمله هو تحليل المادة المجمعة، ومن ثم تتحل المشكلة إلى مجموعة قضايايا تساعد على إدراك ذلك العنصر المعقد (؛). ب- أما الربط: فهو القدرة على تكوين عناصر الخبرة، وتثكيلها في بناء وترابط جديد، أو هو القدرة على إدراك

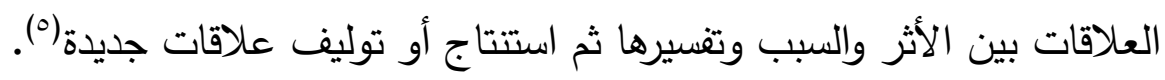

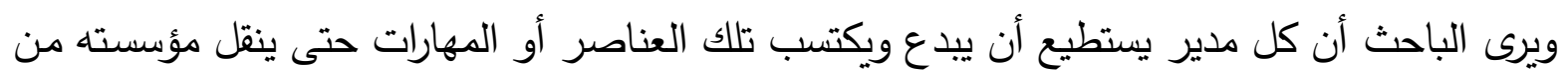

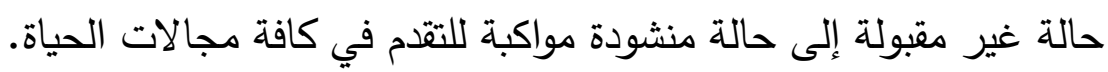

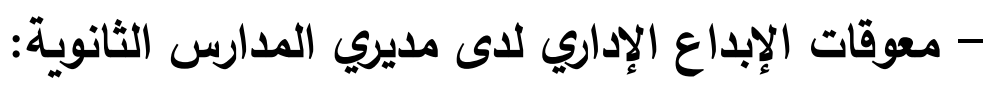

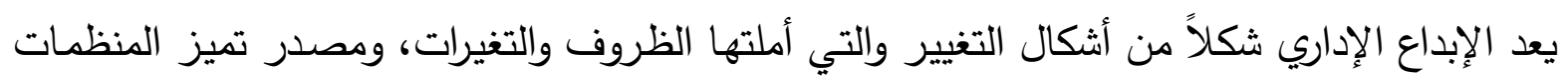

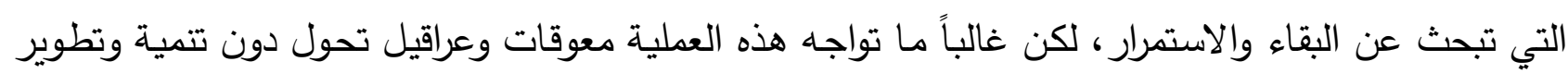

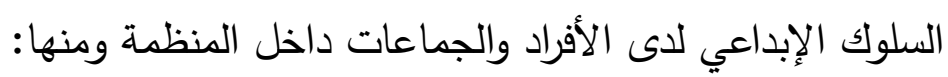

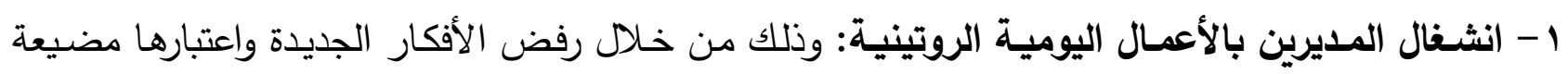
للوقت. r- المركزية في الإدارة: وذلك من خلال عدم الإيمان بتفويض الأعمال الروتينية البسيطة إلى العاملين وعدم الإيمان بأهمية مشاركتهر. r- ضعف الولاء التظظيمي: يؤدي ضعف ولاء وانتماء الفرد للمنظمة التي يعمل فيها إلى الاكتفاء بإنجاز الحد الأدنى من المهمات الموكلة إليه أو يعمل بشكل متقاعس وغير فلاء مبال، وبالتالي لا يتوقع الإبداع منه(؟).

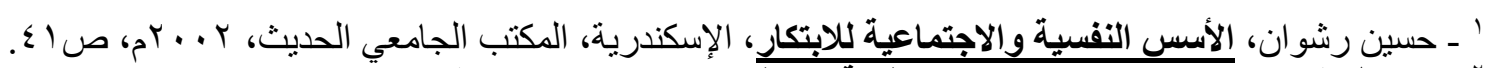

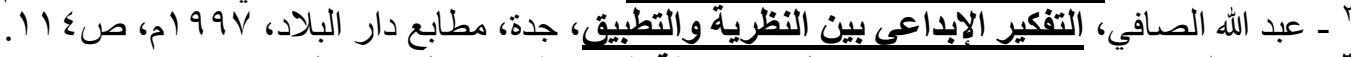

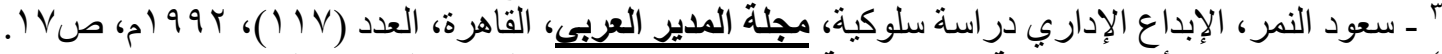

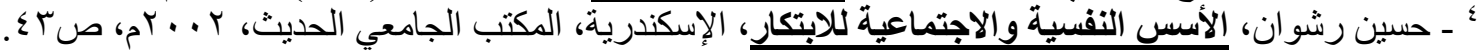

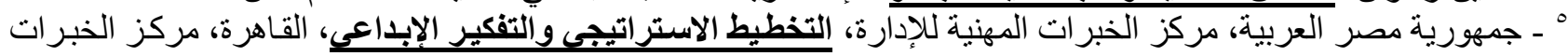

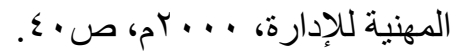

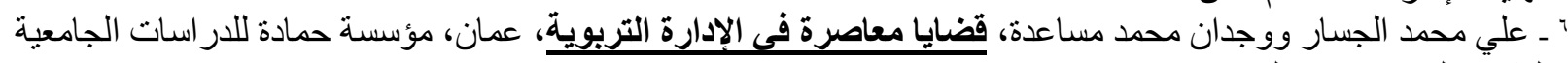


وحتى يمكن التظلب على معوقات السلوك الإبداعي، يجب مراعاة متطلبات سلوكيات الإبداع الإداري

التي يتمثل أهمها فيما يوضحه الثكل رقم ( )

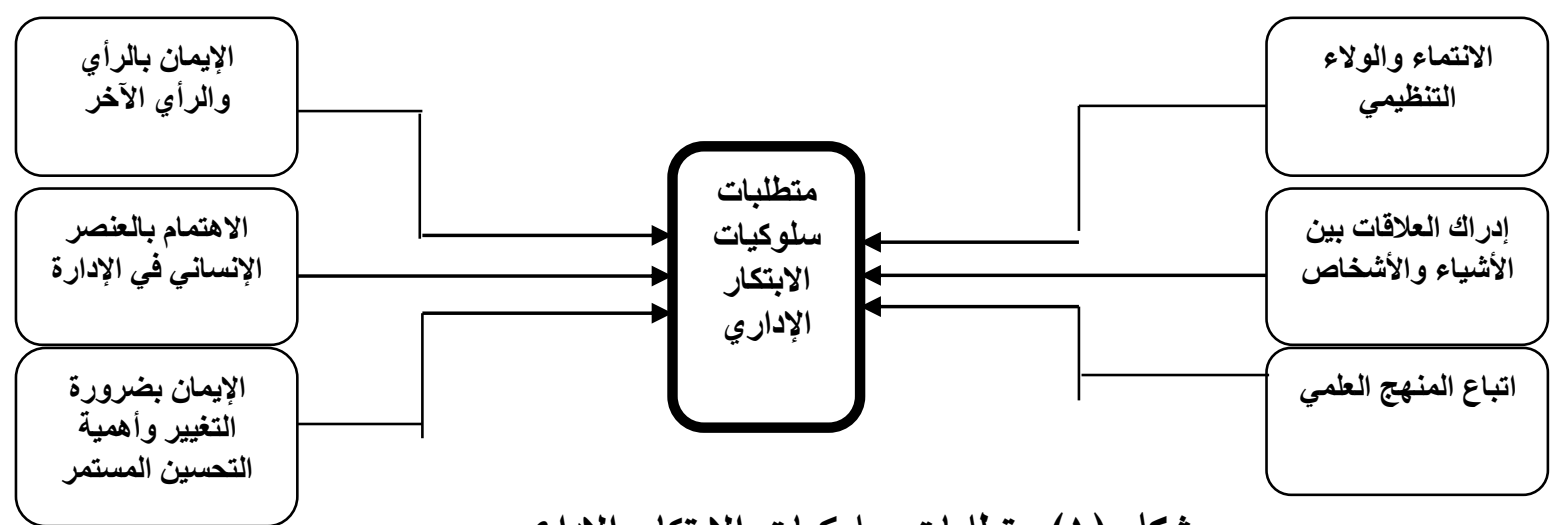

شكل (1) متطلبات سلوكيات الابتكار الإداري

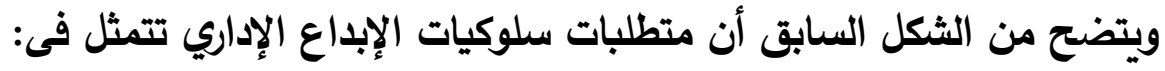

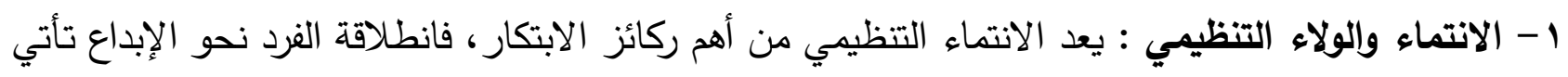

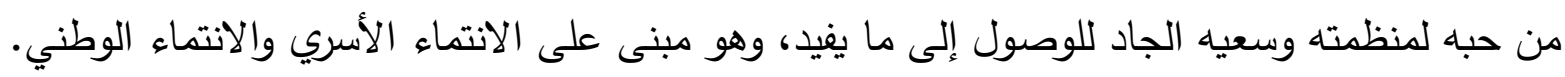

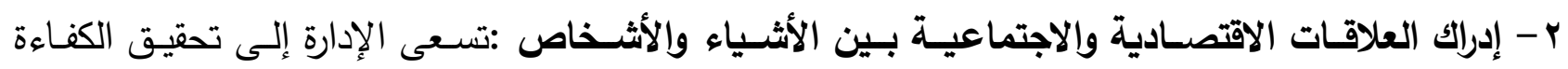

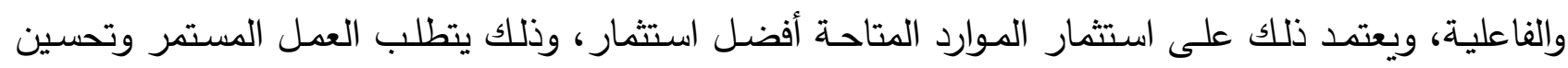

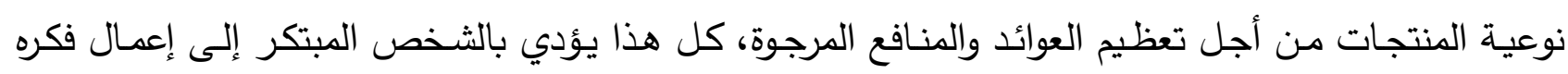
والاجتهاد للوصول إلى الوسائل لتحقيق الأهداف.

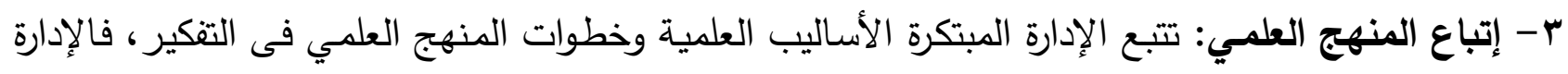
أصبحت مهنـة تعتمد على تتظيم العلاقات القائمسة على تكامل وتفاعل جهود الأفراد في مختلف مستويات التتظيم. ـ - الإيمان بالرأي والرأي الآخر : يسهم المناخ التنظيمي الذي يؤمن باحترام الرأي الآخر والإنصات لله، والسعي

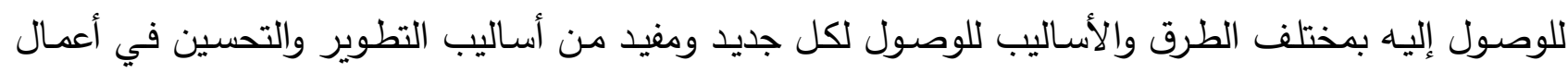
وممارسات المنظمة. ه- الاهتمام بالعنصر الإنساني فى الإدارة: يتحقق مجال كبير من السلوك الابتكاري في منظمات الأعمال التي

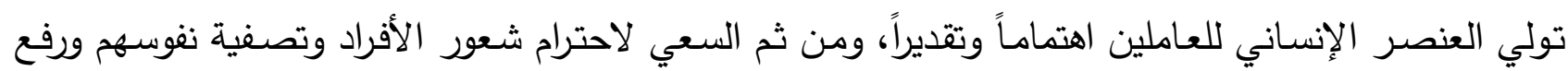

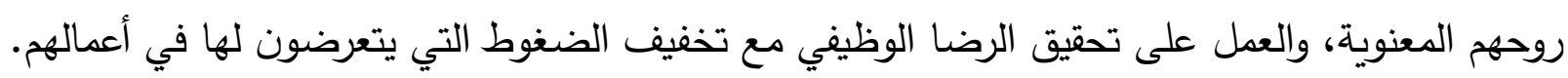

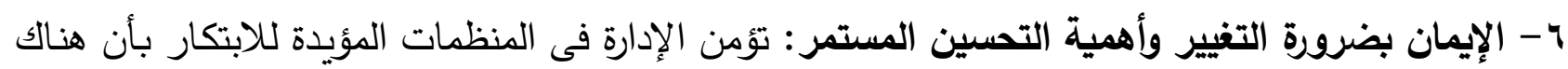

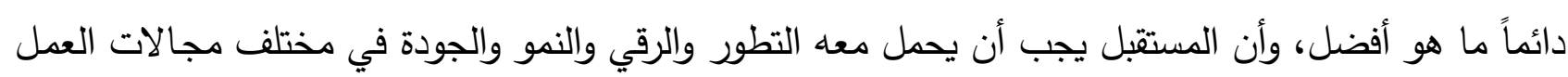




\section{- دواعي الإبداع الإداري في الددرسة الثانوية:}

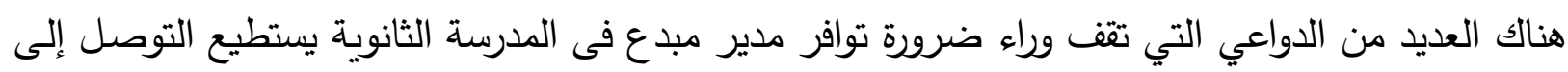

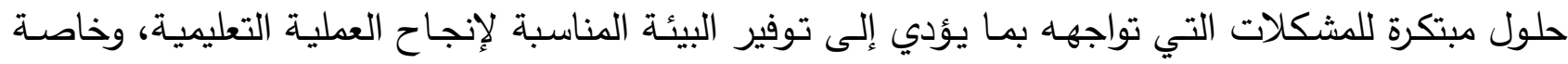

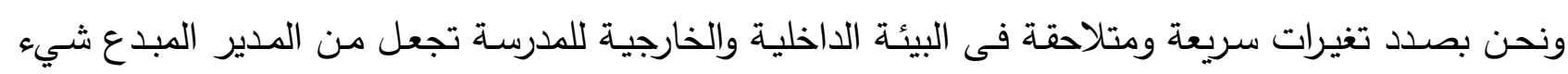

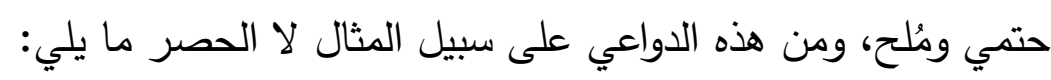

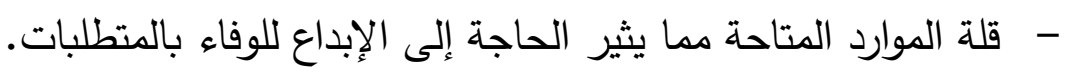

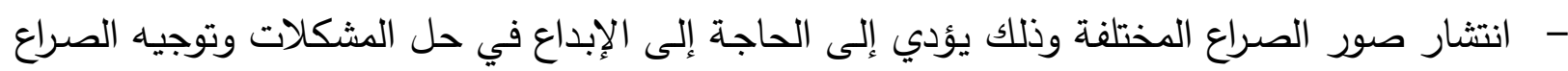

إلى صراع إيجابي تنافسي يكون له أثر إيجابي على المنظمة (1).

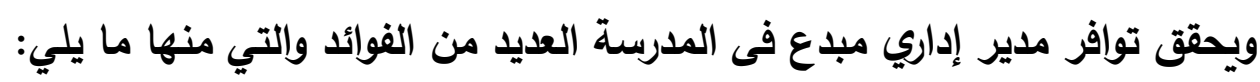
- تقديم أفكار جديدة لجميع العاملين والتي تمكنهم من حل المشكلات بطرق مبتكرة والنظر إلى الأمور نظرة مختلفة. - دعوة الطلاب لمناقثة وتقديم المبادرات الجديدة من خلال إعطائهم مناصب قيادية وإمدادهم بالأنثطة

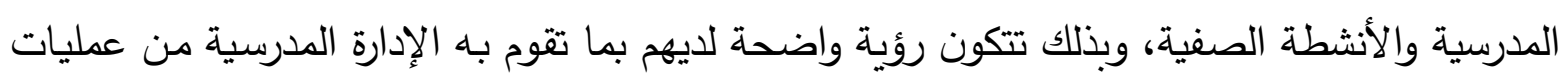

$$
\text { تحسين، وذلك له أثره الإيجابي على أداء الطلاب الان. }
$$

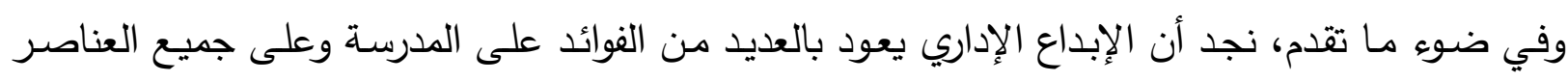

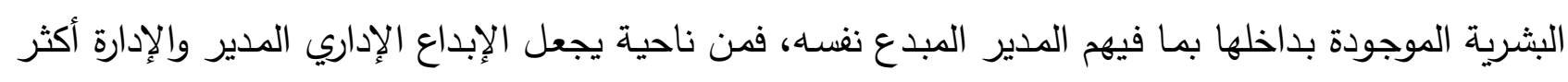

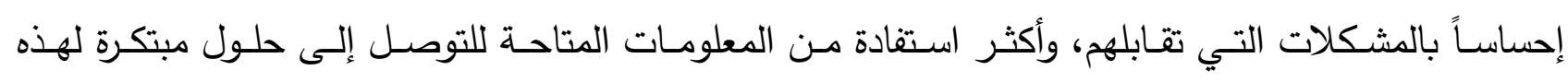

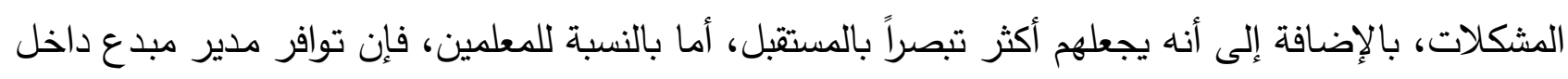

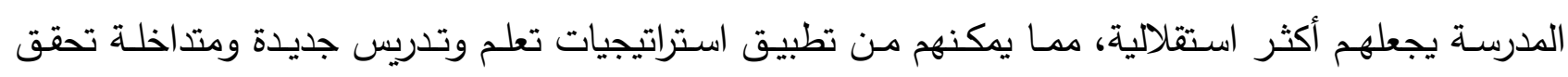

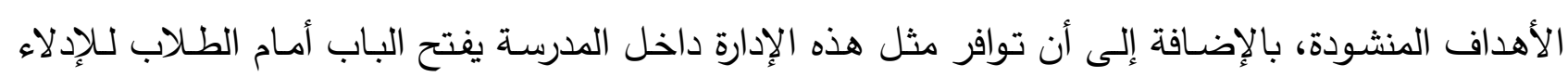

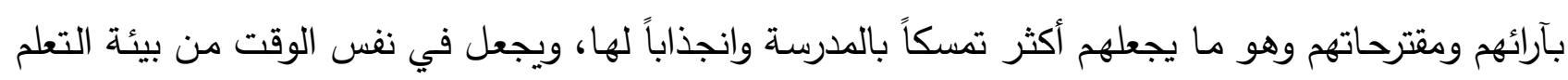
بالمدرسة بيئة شيقة وجذابة ويعيد حب المدرسة مرة أخرى في نفوس الطلاب.

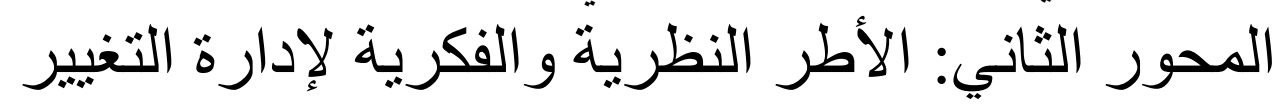

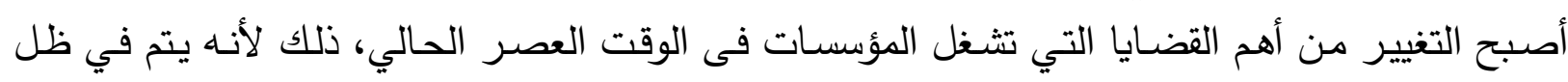

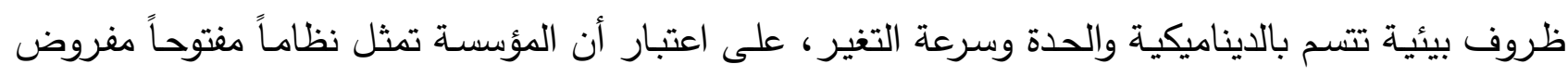

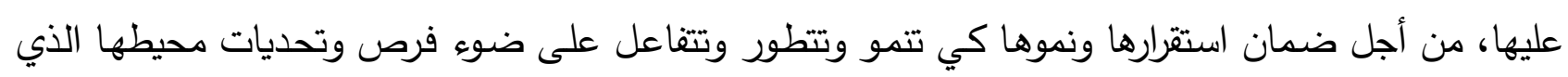
تنشط فيه.

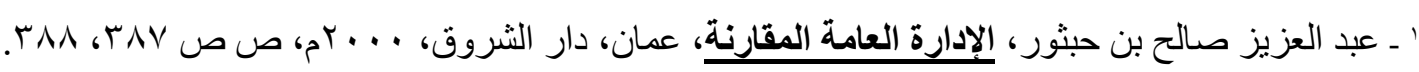
2 - Brookly, Foster, A School culture Of Innovation And Creativity, Minnesota: The University of Minnesota, 2001, P.p1,2. 
تسـى إدارة التغييـر في المـدارس لإحداث التوافق المرغـوب بينها وبين بيئتها، وكلمـا استطاعت التتبؤ بالتغيرات المتوقعـة والمحتملة داخلياً وخارجياً، واستعدت لهذه التغيرات بتطوير مماثل لأهدافها واستراتيجياتها ونظمها الإدارية، كلما كانت أكثر قدرة على تحقيق تواجد مؤثر ومستمر في بيئتها المحيطة(').

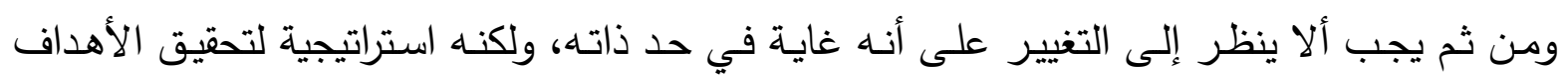

العامة للمؤسسة من خلال إجراء التطوير على مختلف مستويات دورة حياة تلك المؤسسة(؟). ونستنتج مما تقدم أن التغيير هو الانتقال من حالة إلى حالة أخرى ممكن أن تكون أفضل أو أسوأ ولكنها حالة جديدة، وهو إجراء تعديل في الوضع الراهن إلى وضع آخر من أجل تحقيق هدف ما. - العوامل التي أدت لتبني إدارة التغيير: خلال العقد الماضي، واجهت العديد من المؤسسات ضرورة إجراء التغيرات الضرورية التي من شأنها تحسين الأداء ومساعدتها على البقاء والتتافسية. وينظر إلى التغيير على أنه دورة الحياة للمؤسسة، ولذلك فلا نندهش إذا وجدنا مزيـدًا من التحليل ومناقشـة العديد من أنواع التغيير ، والبحث عن الإدارة المناسبة لإحداث التغيير فى المؤسسة، لأن التغيير هو الذي يحدد مستقبل المؤسسة ومدى مجاراتها للحداثة والواقع الجديد. ومن العوامل التي أدت لتبني إدارة التغيير • ا- التقدم العلمي والتكنولوجي في مجال جمع المعلومات وتحليلها ونقلها وما حققه من توفير في الوقت والجهد. r- أصبح العالم شاشة صغيرة(r). - أهداف إدارة التغيير:

إن التغيير هو عملية إدخال تحسين أو تطوير على المؤسسة التعليمية بحيث تكون مختلفة عن وضعها الحالي، وبحيث تتمكن من تحقيق أهدافها بشكل أفضل. وعليه فإن هناك العديد من الأهداف العريضـة للتغيير والتي يجب على المدرسة الثانويـة مراعاتها أثناء إدارة هذا التغيير ، ومنها ما يلي: - زيـادة قدرة المدرسة على العمل والتكيف مـع البيئة المحيطة سواء الحالية أو المتوقعة وتحسين قدرتها على هـى البقاء والنمو. - الكثف عن الصراع بهدف إدارته وتوجيهه بشكل يخدم مصالح المدرسة(؛). - منح العاملين في المنظمة فرصة إظهار أقصى طاقة يملكونها من المهارات والإبداع نحو العمل والإنتاج. - العمل على رفع القدرة الإنتاجية للمنظمة وفاعليتها في تحقيق الأهداف المرجوة فيها(').

' ـ ـ أمل مصطفى صح عصفور، قيم ومعتقدات الأفراد وأثرها على فاعلية التطوير التنظيمى، القاهرة، المنظمة العربية للتنمية الإدارية، 2 - Carter McNamara, Basic Context for organizational change. PhD, Retrieved from https://managementhelp.org/organizationalchange/basics.htm On 23/6/2018

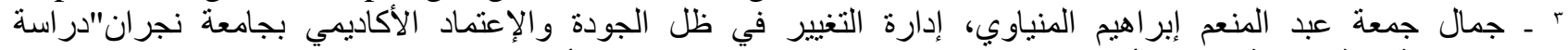

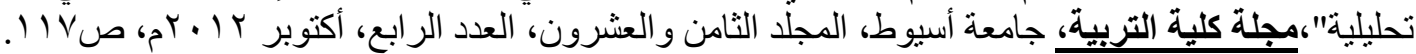

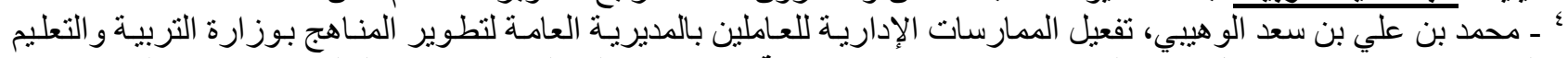

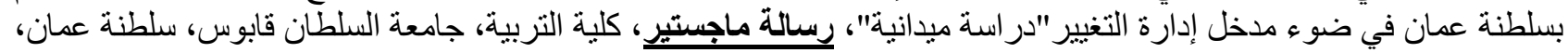


يعتبر التغيير تحركًا ديناميكيًا، باتباع طرق وأساليب مستحدثة ناجمة عن الابتكارات المادية والفكرية،

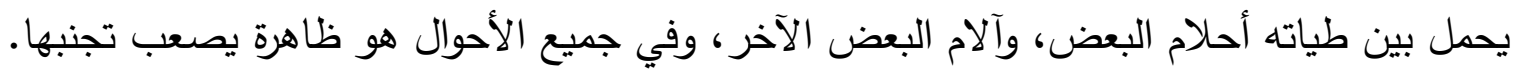
وترجع أهمية التغيير لوجود أمور عدة في المنظمة يتم حدوثها، مثل تسارع أساليب التغيير المختلفة في عصر التكنولوجيا، إذ يجب على المديرين إحداث ذلك التغيير من أجل مواجهة التحديات المعاصرة، وإثراك الأفراد العاملين في التخطيط للتغيير وإدارته بطريقة مبدعة ومتميزة من أجل نجاحها، آذات. - مراحل التغيير:

هناك الكثير من المواقف التي تساعد المدير على القيام بتغيير طرق العمل وأدواته، وترتبط فاعلية التغيير بقدرة المدير على إحداث هذا التغيير. ووفقًا لمنهجية جون كوتر وهو أحد رواد التغيير في العالم، تتم عملية التغيير من خلال ثمانية خطوات عملية كالتالي: 1 - تحديد الحاجة للتغيير ومدى ضرالئ

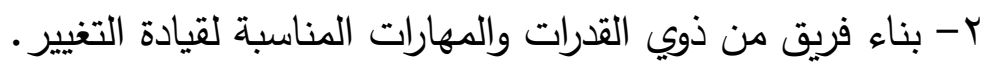

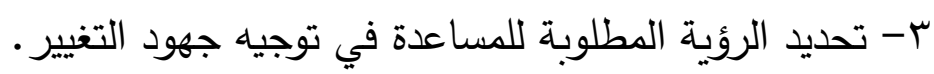

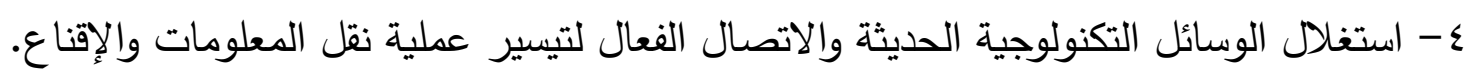
ه- تقوية الأداء وفتح المجال للمشاركة وإبداء الرأي. צ- تحقيق النجاح من خلال وضع أهداف ممكنة ومبادرات سريعة التحقيق.

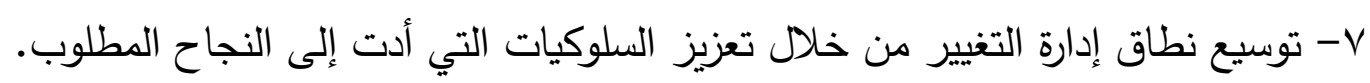

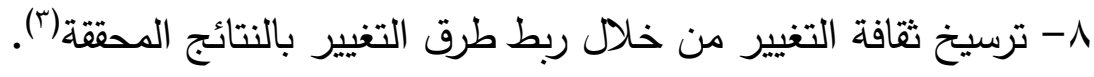
- متطلبات إدارة التغيير:

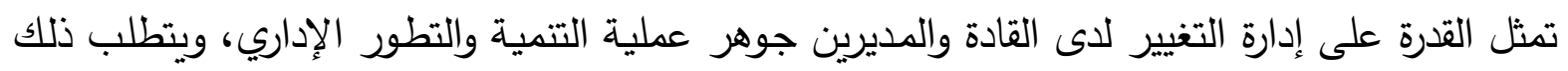

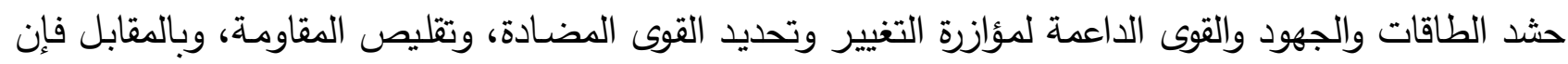

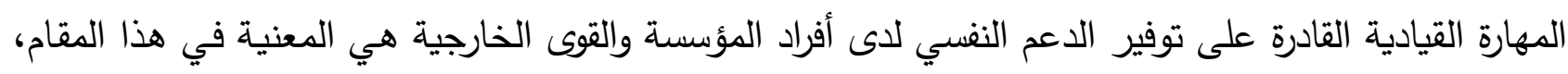
ويمكن توضيح ذلك بما يلي: 1- وجود إدارة جادة قادرة على التحول من منطلق الاستيعاب والإحاطة والثمولية للمواقف، وقناعة بضرورات التغيير.

1 - Pattanayak, B. \& Mishra, P.K, Change for Growth: Understanding Organizational Development, New Delhi, Wheeler publishing, 2009, p.24.

$2^{2}$ - Harvey, D \& Brown, D, An Experiential Approach to Organization Development, $7^{\text {th }} \mathrm{Ed}$, Prentice Hall, 2006.

${ }^{3}$ - Kotter, J., Leading Change: Why Transformational Efforts Fail, $\underline{\text { Harvard Business Review }}$ Press, 1995, p.61. 
r- القدرة على المبادأة والإبداع لإحداث التغيير في عناصر المؤسسة. ب- توفير المناخ التظظيمي الملائم للتغيير، ووضوح استراتيجيات فاعلة وبرامج متابعة مستمرة للارتقاء بالإدارة وصولاً إلى الأهداف المتوخاة من التغيير ('). 9- أن تتسم إدارة التربية والتعليم بالمرونـة وقابليـة التجديد في برامجها وأهدافها وبنيتها التنظيمية وعملياتها

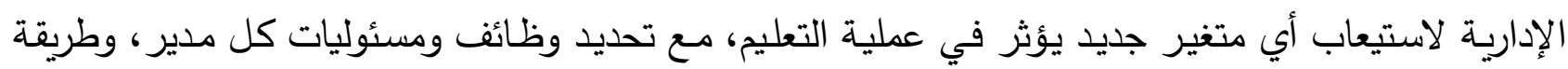
ونوعية وأساليب التدريب المطلوبة والذي يعتدد بشكل رئيس على الابتكار والتجديد(؟). - دور المدير في إدارة التغيير: إن دور الكدير يتمثل فى القدرة على التعرف إلى القوى التي تدعو إلى التغيير فقد تكون من خـارج

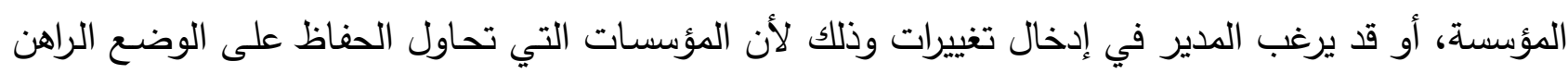

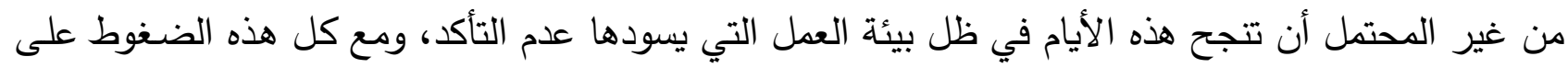

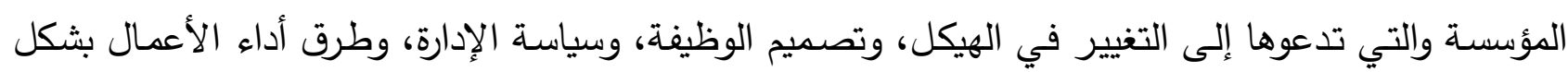
كامل، ولهذا يستلزم نجاح المدير في إدارة التغيير مراعاة عناصر أساسية، ولفئ. العناصر الأساسية لنجاح مدير التغيير: • تعريف التغيير بدقة ووضوح. - التخطيط السليم وتحديد من سيتأثر بالتغيير ومن المطلوب موافقته على التغيير، ومن المسئول عن تخصيص

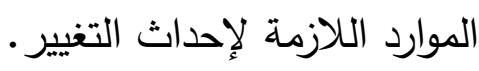

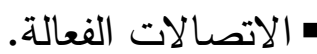
• التطبيق المناسب(r) - (ب).

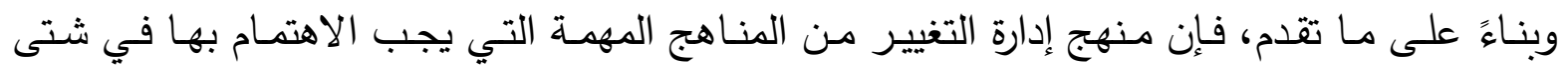

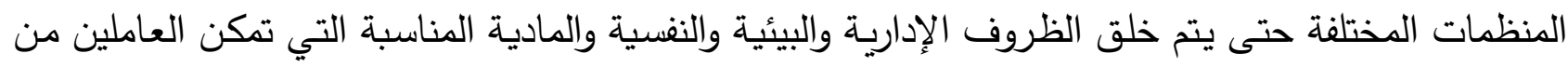

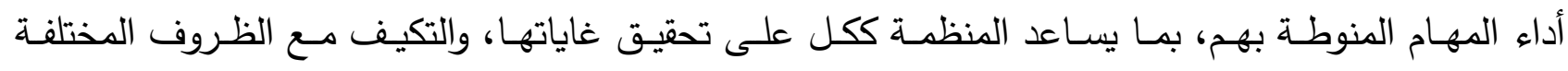
والمستجدات الطارئة، وحتى تصبح قادرة على مواجهة التحديات والتطورات السريعة المتلاحقـة في البيئتين الدولية والإقليمية أو على المستوى المحلي.

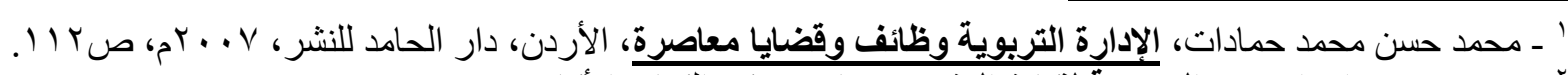

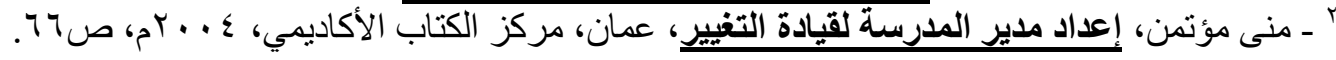
3 - Daft Richard L.\&Noe Raymond A, Organizational Behaviour, New York, America, Harcourt College Publishers, 2001, p.620. 


\section{المحور الثالث: ملامح إدارة المدرسة الثانوية العامة في جمهورية مصر العربية}

تعتبر مرحلة التعليم الثانوي العام في مصر من أهم المراحل التعليمية التي تستدعى إعادة النظر، فهي

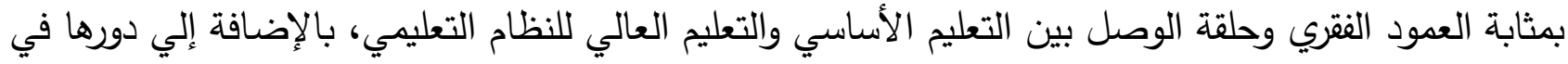

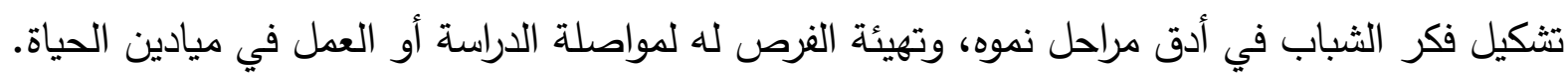

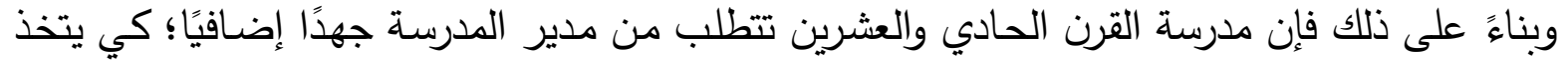

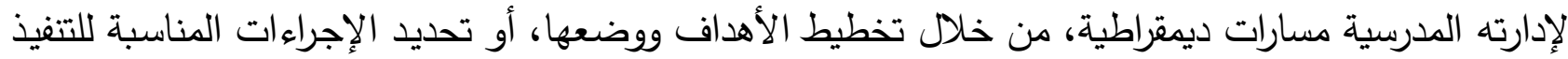

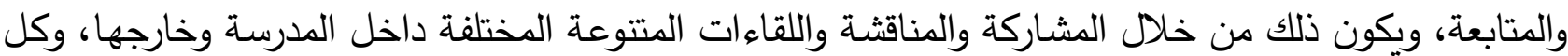

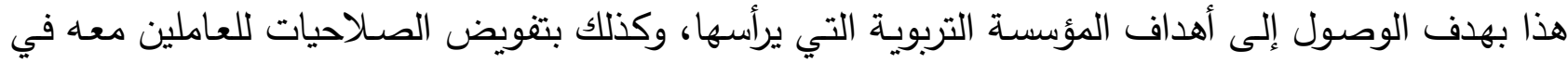

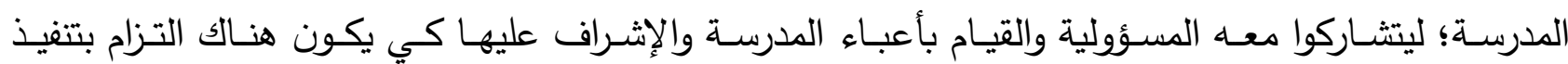
(') الأهداف. (1)

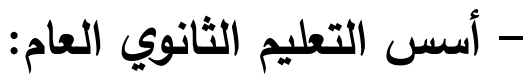

يشغل التعليم- بكافة مراحله - اهتمام العديد من القائمين عليه من أجل تحسينه وتطويره، ومن ثم تحقيق

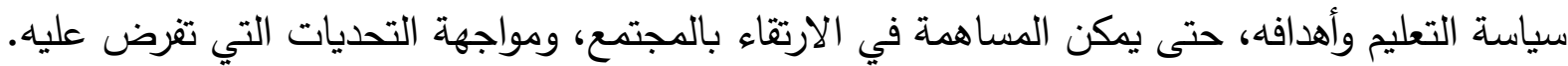

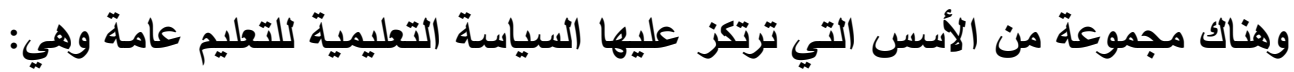

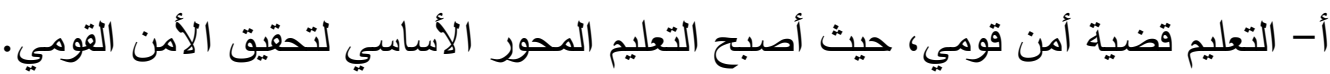

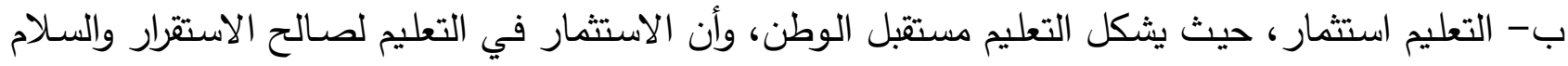
الاجتماعي، ولذا فالتعليم أقوى دعامات السلام الاجتماعي. ج- إدخال التكنولوجيا الدتطورة وتتمية المهارات الحياتية والاتصالية.

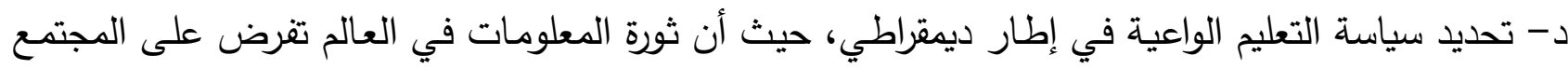

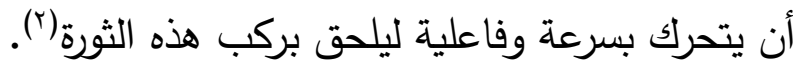

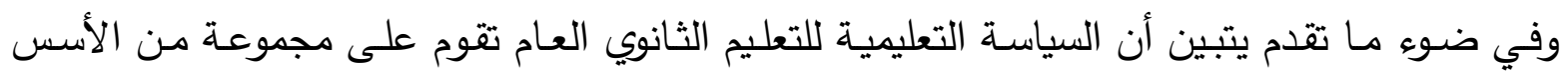
والمرتكزات التي ينغي أن تصوب أهداف هذا النوع من التعليم نحوها لاستهافها وتحقيقها.

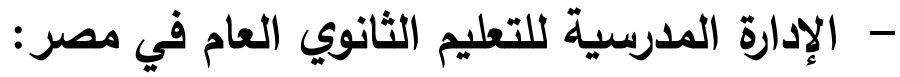

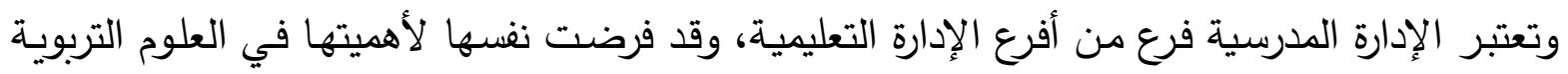
بعد أن أصبح معناها الجديد واضحاً كعلم وفن ومهارة، واندثر مفهومها التقليدي الذي ظل فترة الترة من الزمن.

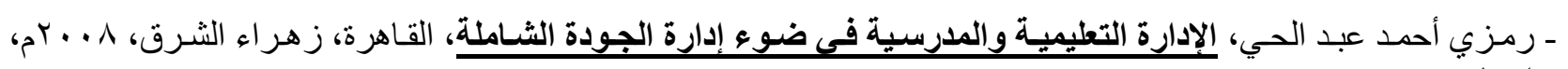

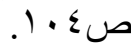

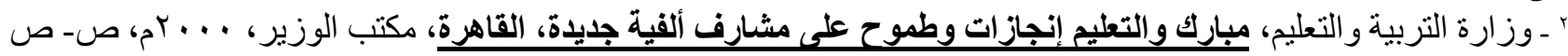


ويتضـح مهـا سبق أن وجـود إدارة مدرسية علميـة حديثة مـن المتطلبـات الضـرورية لتحقيق فاعليتها

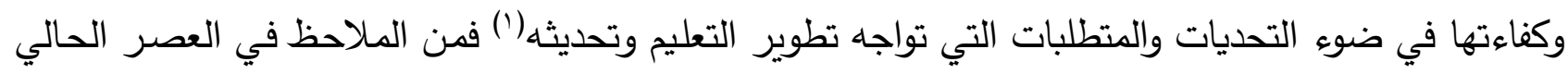

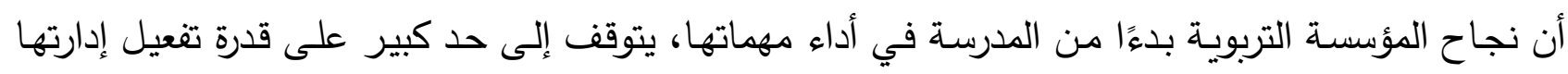

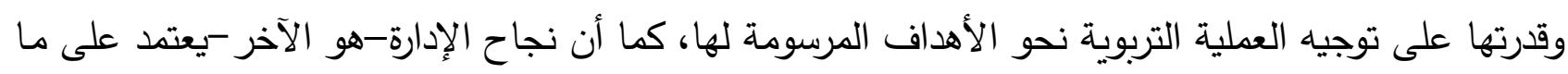
يمتلكه الإداري من قدرات ومهارات، وما يتصف بها من صفات ومميزات ومات وما يعرفه من معارف ومعلومات تتعلق

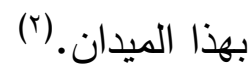

ومن ثم تهتم الدولة بتطوير إدارة التعليم الثانوي العام في مصر بصفة عامـة وإدارة الددرسة الثانويـة

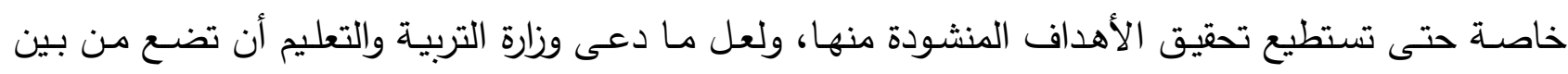

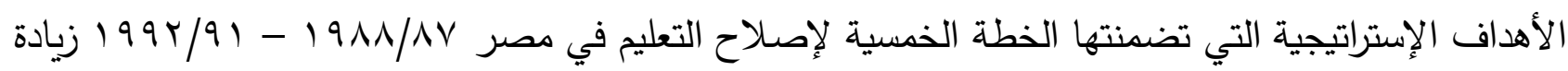

فاعلية الإدارة التعليمية وذلك من خلال (r).

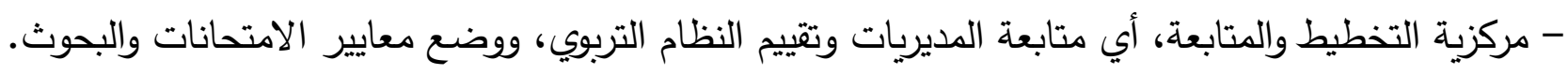
- لا مركزية التنفيذ في المحليات. - إيجاد نظام قادر على الوفاء باحتياجات التعليم من المباني والتجهيزات الدرسية. - إعداد الكوادر الفنية اللازمة. - الأخذ بالوسائل التكنولوجية الحديثة في الإدارة. ولقد شهدت السنوات الأخيرة اتجاهًا جديدًا في الإدارة المدرسية يهتم بالتلميذ من خلال الاهتمام بجميع الإداني

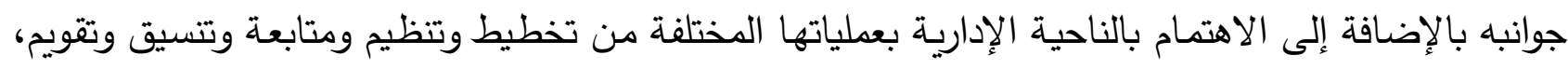

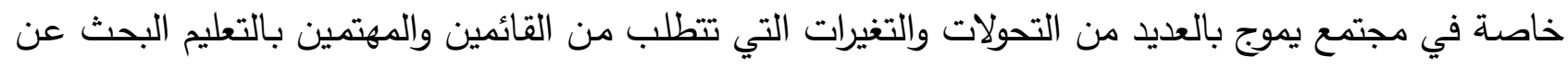

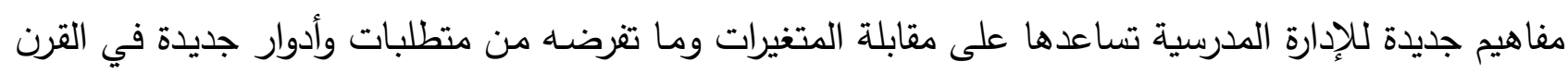
الحادي والعشرين. - أهمية الإدارة المدرسية في التعليم الثانوي العام تعتبر الإدارة الددرسية جزء من الإدارة التعليمية، والإدارة التعليمية فرع من فروع الإدية الإدارة العامة. وحيث

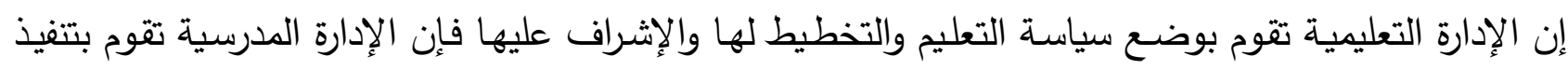
هذه السياسة على أرض الواقع ومن هنا تتبع أهمية الإدارة المدرسية.

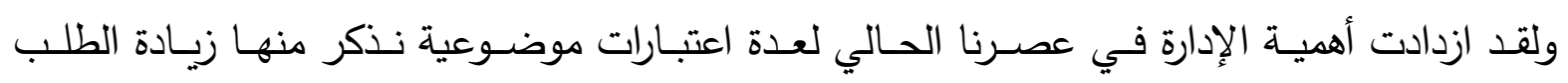

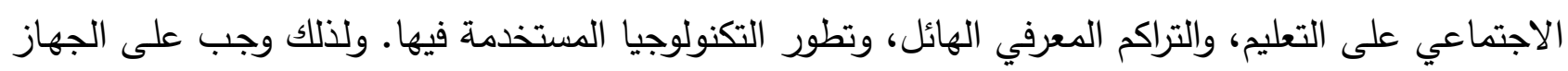

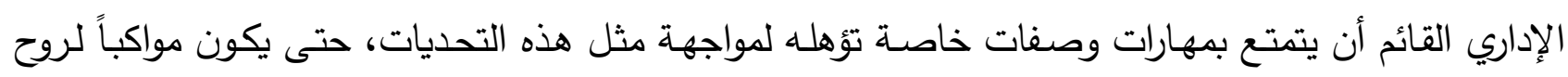

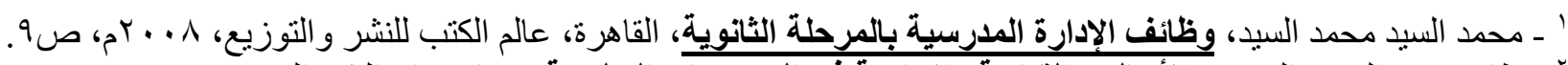

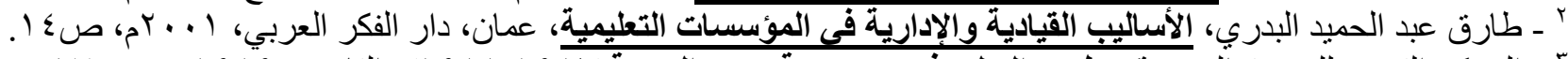

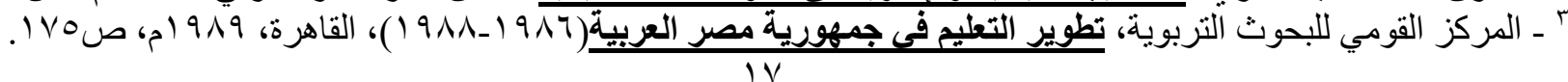


العصر، فإدارة المدرسة مكلفة بتطوير الأداء وتحسين أساليب وطرق العمل وزيادة الكفاية الإنتاجية، كما أنها مطالبة باستخدام التكنولوجيا كوسيلة لإحداث التتمية والعمل بثكل عام للتحرك نحو الأفضل الإدل (1). - أهداف الإدارة المدرسية في التعليم الثانوي العام: باسنية

تشتق أهداف المدرسة الثانويـة العامة من أهداف التربية، والتي تثـتق بدورها من الأهداف والسياسـة

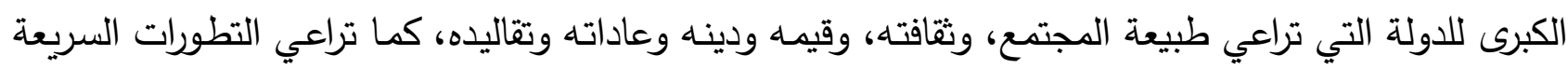
والمتغيرات التي يمر بها العصر.

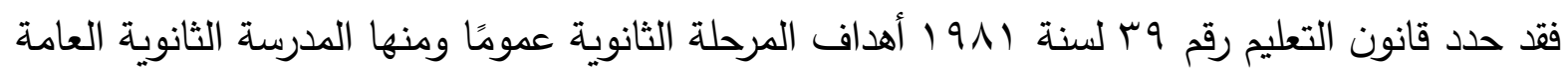

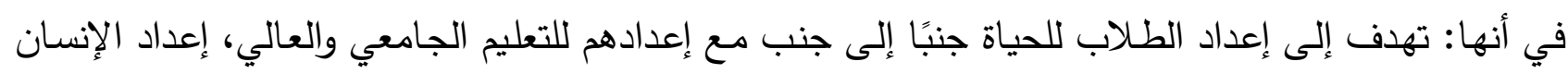

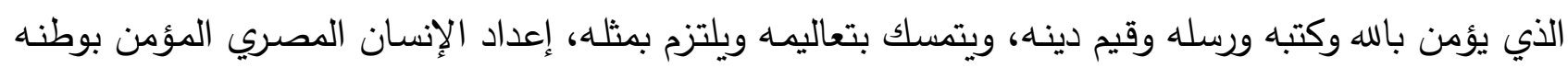

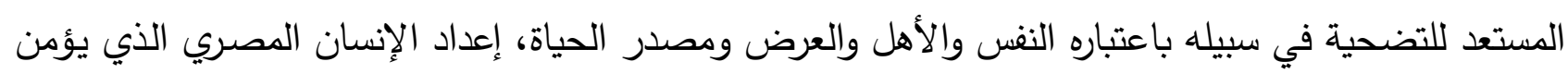

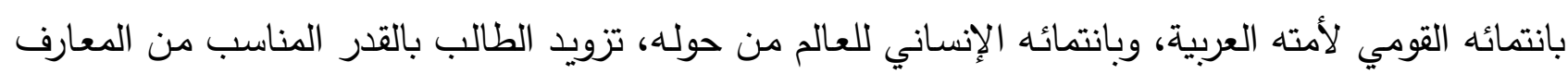
والمهارات اللازمة لتحقيق ذاته(ب). وتتأثر أهداف الإدارة المدرسية بالتطور الذي تعيشه التربية بشكل عام في جميع جوانبها؛ ومن ضمنها

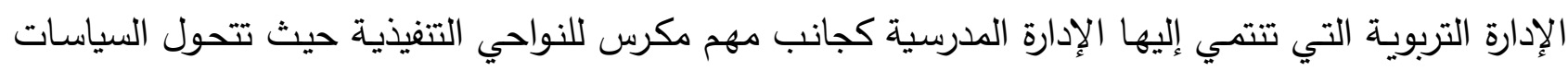

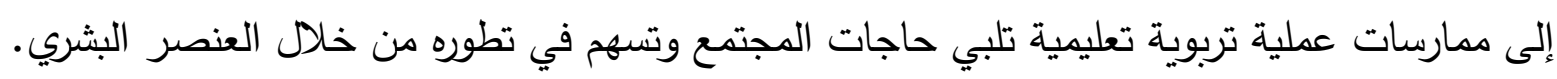
الأسس التي يعتمد عليها نجاح مدير مدرسة التعليم الثانوي العام يعتمد نجاح مدير المدرسة في مهمته على عوامل منها :

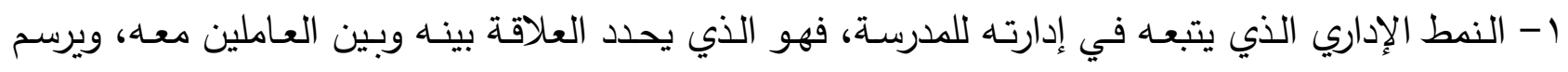
معالمها، بحيث ينجح في تتسيق جهودهم وتضافرها لبلوغ أهداف المدرسة، أو هو نمط يعمل على تشتيت هذه الجهود وتضييعها.

ب- نموه المهني المستمر حتى يتمكن من تزويد العاملين معـه بالأفكار والمعارف اللازمـة لتطوير العملية التربوية. r- ميله للتجديد وبخاصة في ميدان عمله، بحيث يتجه نحو التطوير والإبداع.

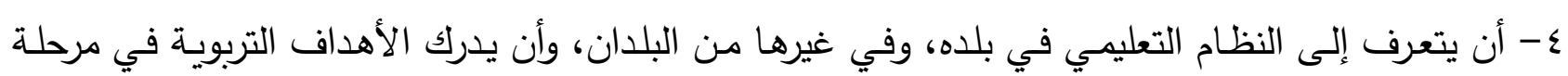

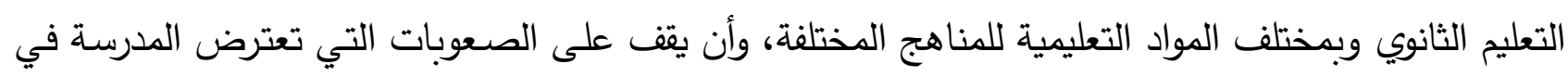
سبيل بلوغها الأهداف التربوية، للعمل على تلافيها (ان.).

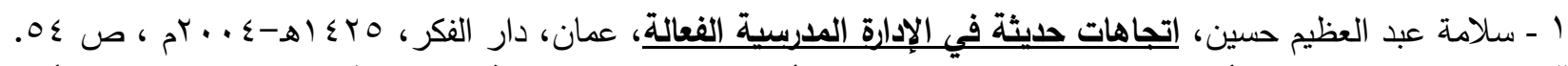

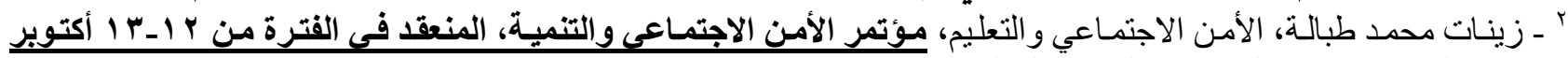

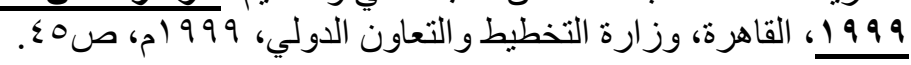

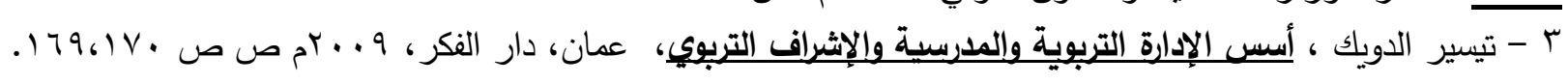


- أهم التحديات التي تواجه الإدارة المدرسية في التعليم الثانوي العام في القرن الـ I ب.

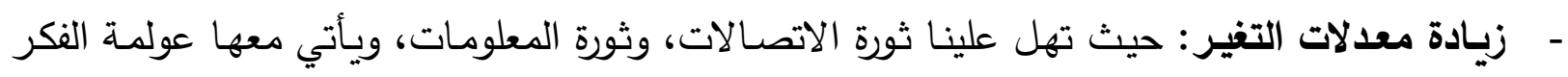
الإداري والاقتصادي. - ش شدة المنافسة: حيث زادت نسبة المعاملات الدولية والعولمة الاقتصادية، ولا شك أن مثل هذه الأمور

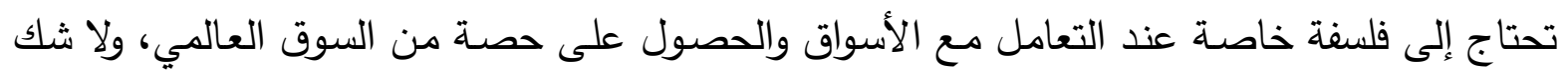
أن ذلك لن يتأتى إلا من خلال عمليات الإبداع وخاصة في المنتج والتسويق.

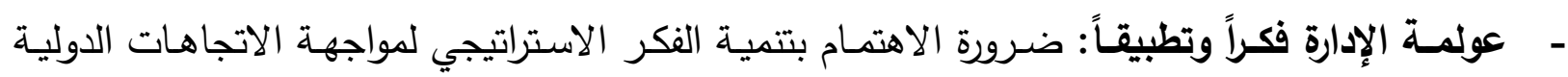
وخاصة في المجال الإداري والاقتصادي. - التغيرات التكنولوجيـة: حيث أصبحت أغلبيـة المؤسسات تعتمد على الأسـاليب التكنولوجيـة من أجل الحصول على ميزة تتافسية تسهم في سيطرتها على المواقف من حيث الزمان والمكان. - تغير طبيعة قوى العمل: حيث تغيرت نوعية الاستعداد للعمل، وتغير المدى العمري للعامل، بالإضافة فئل

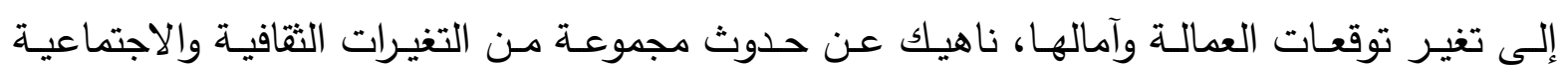

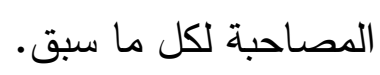
- التحول من الفكر الصناعي تجاه الفكر المجتمعي: حيث تقود المعرفة الإدارية المؤسسات باستمرار

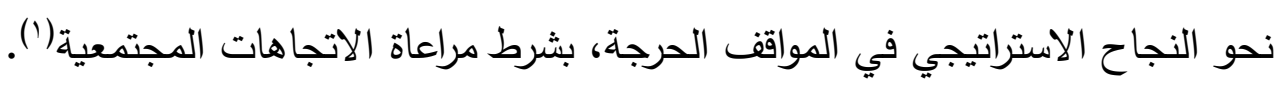
- سمات وخصائص الإدارة المدرسية الناجحة في مدارس التعليم الثانوي العام: تتسم الإدارة المدرسية الناجحة وتتميز بمجموعه من الخصائص المميزة لها وذلك لكي تنجح في أدارئ أداء

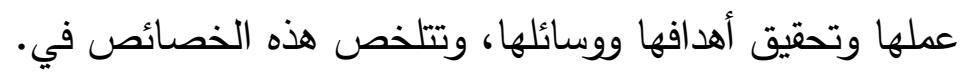

ا- مواكبة الجديد في مجال الفكر التربوي والإداري، وذلك لزيادة فعالية الإدارة أثناء تحقيق أهدافها (†).

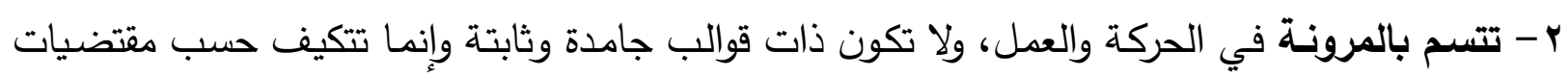

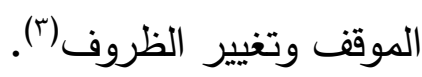
ومن خـلال ما تقدم تتضـح أهمية الإدارة المدرسية من خـلال الخصائص التي تتميز بها، وكونها ضـرورة حتمية للعمل المدرسي فهو لا يقوم ولا ينهض إلا بها وذلك لتعدد وتتوع وتثعب المهام التي تتم من خلالها، ولذلك فإن ميدان الإدارة المدرسية يحتاج لكثير من الدعم والمساندة.

1 - الهيئة القومية لضمان جودة التعليم والاعتماد، جودة أداء الإدارة العدرسية"القيادة-الحوكمة"، الإصدار الأول ، و . بYم،

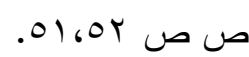

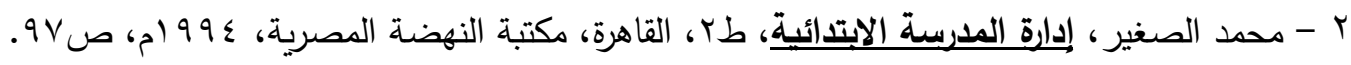

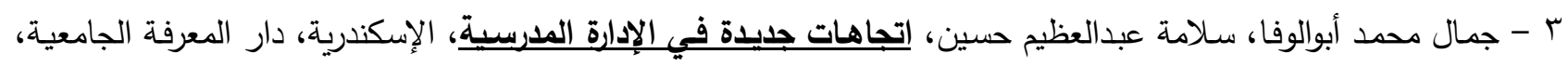

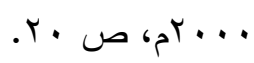




\section{- تطوير الإدارة المدرسية بمدارس التعليم الثانوي العام:}

أثرت ثورة المعلومات وثورة التكنولوجيا والاتصسالات تأثيراً واضحاً على ميدان الإدارة عموماً والإدارة

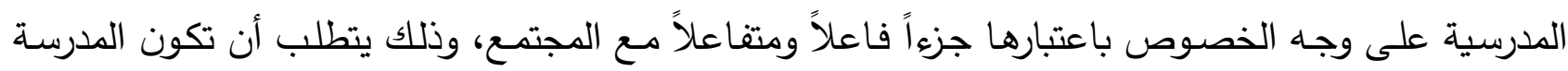

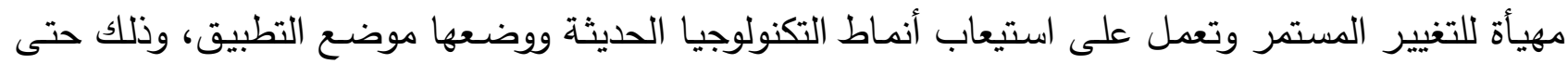
تلحق بأسباب التقدم العلمي والتكنولوجي. ويعد التطوير الإداري لب أي تطور حضـاري وتربوي، لأن كل تطوير للتعليم قوامسه تطوير إدارته.

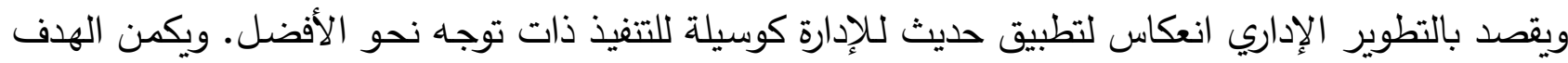

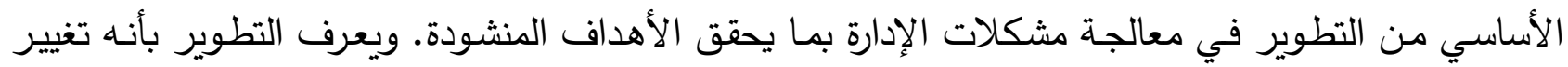
مخطط لتحقيق أهداف المنظمة، ورفع كفاءتها وفعاليتها بصورة عامة.

\section{أهم نتائج الاراسة : أن}

1- ندرة النظر إلى مشكلات العمل من زوايا متعددة.

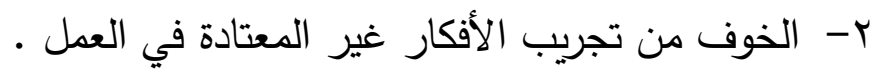

ب- سوء التخطيط لمواجهة المشكلات التي يمكن حدوثها.

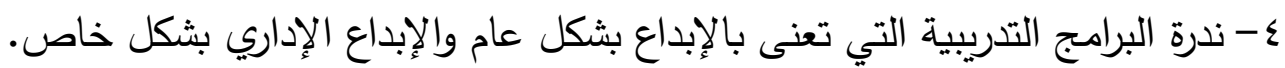

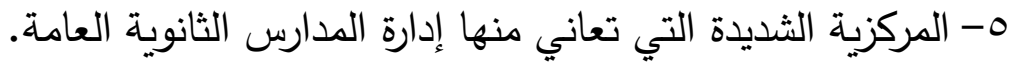
צ- قصور نشر ثقافة التغيير بين المجتمع المدرسي. V- قصور في وضع الأهداف التي تؤدي إلى تبني سياسة التغيير • ^- قصور في توعية العاملين على نطاق واسع لفهم التغيرات الجديدة. 9- ندرة إقامة برامج تدريبية لمديري المدارس الثانوية العامة تعنى بأساليب إدارة التغيير • • 1- تعارض القوانين واللوائح القديمة مع عمل مدير المدرسة في إحداث التغيير. 


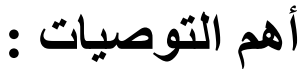

ا- تثجيع العاملين على ممارسة الإبداع الإداري، من خـلا تقديم الحوافز والمكافآت للأفراد المبدعين ذوي الإنجاز العالي.

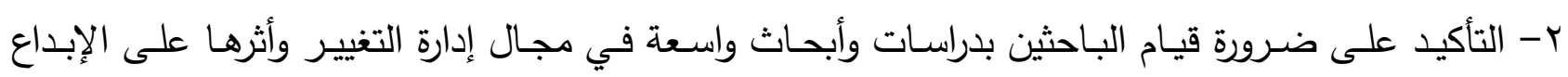
الإداري، إضافة إلى الاهتمام بمخرجات هذه الدراسة ومحاولة الاستفادة منها فى الواقع. r- توفير ظروف العمل التي تساعد على توليد الأفكار المبدعة.

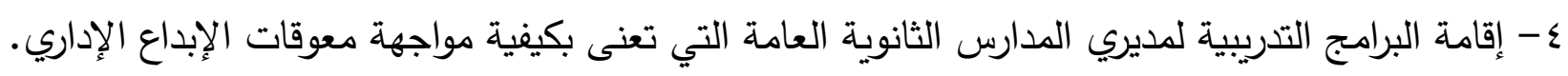

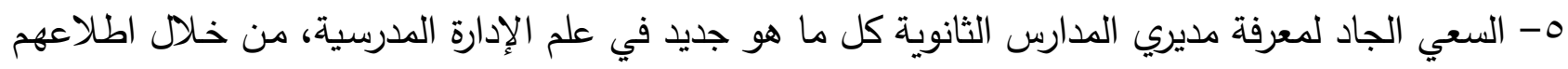

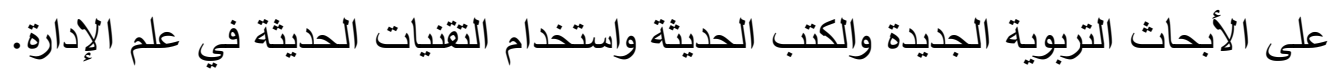
צ- تقليص عدد المستويات الإدارية وزيادة اللامركزية في اتخاذ القرارات كنتيجة لعملية التغيير. V - مراجعة التشريعات بشكل دوري بهدف التجديد والتطوير وتحديثها بشكل مستمر .

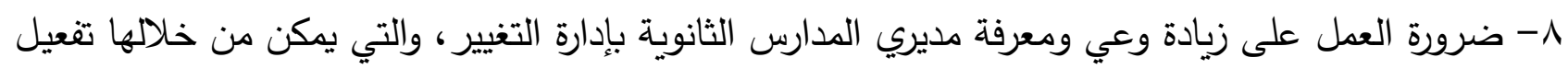
الإبداع الإداري.

9- عقد نـدوات ومؤتمرات علميـة وتثقيفيـة حـول قضـايا التغييـر ومطالب التحديث والتطـوير ، وأهميـة دور

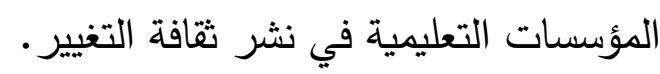

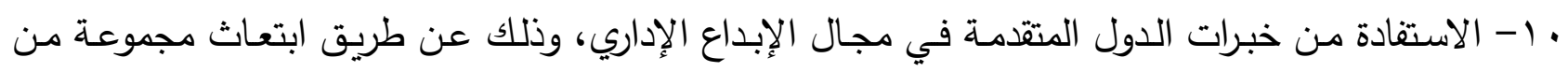

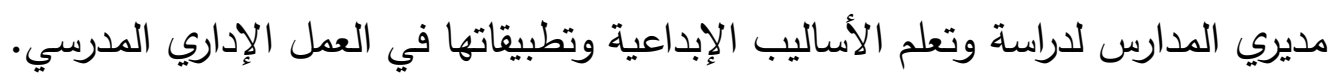




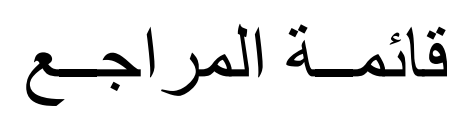

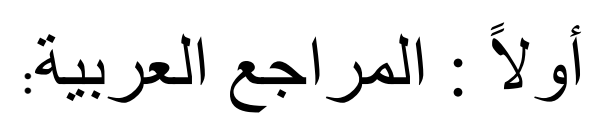

ا. أحمد حسين الرفاعي، مناهج البحث العلمي-تطبيقات إدارية واقتصادية، عمان، دار وائل للنشر

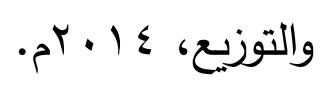

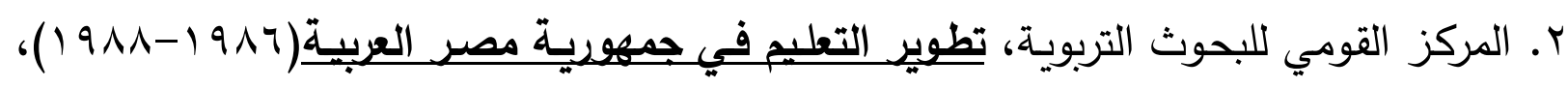

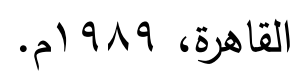
r. الكيئة القومية لضمان جودة التعليم والاعتماد، جودة أداء الإدارة الددرسية"القيادة-الحوكمة،

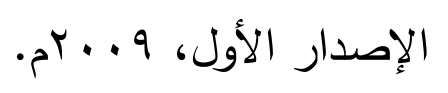

ع. أمل مصطفى عصفور، قيم ومعتقدات الأفراد وأثرها على فاعلية التطوير التنظيمي، القاهرة،

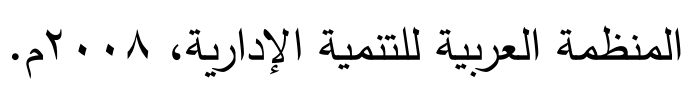

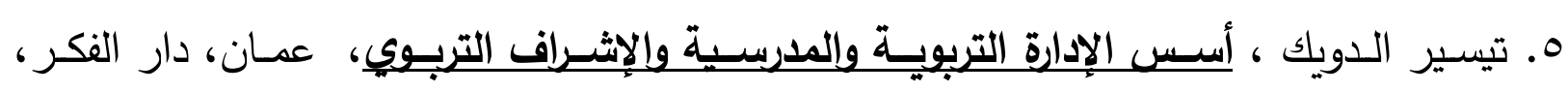
. 1. جمال جمعة عبد المنعم إبراهيم المنياوي، إدارة التغيير في ظل الجودة والإعتماد الأكاديمي

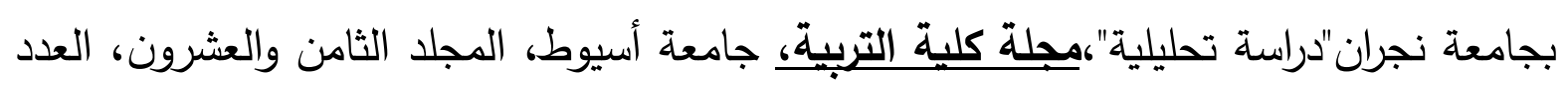

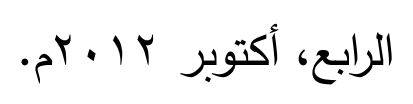

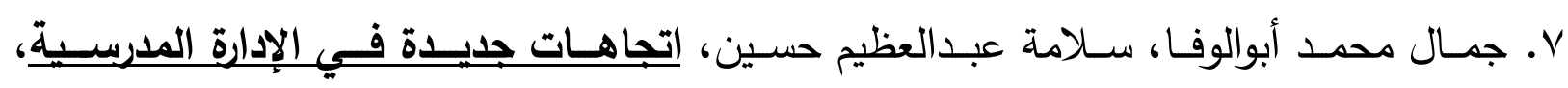

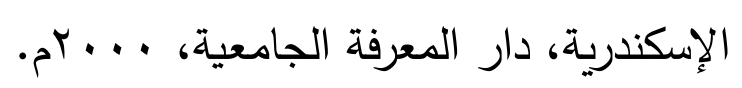

^. جمهورية مصر العربية، مركز الخبرات المهنية للإدارة، التخطيط الاستراتيجي والتفكير الإبداعي، الإعي،

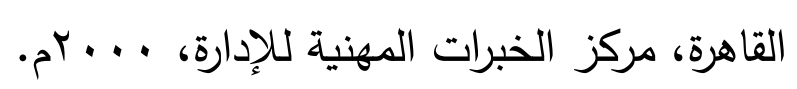

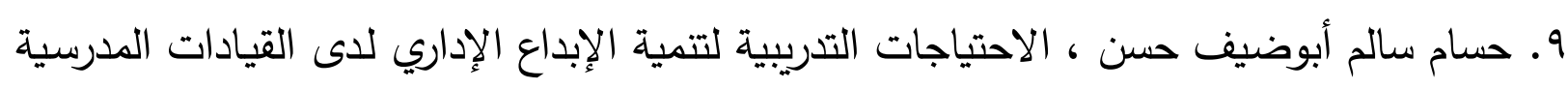

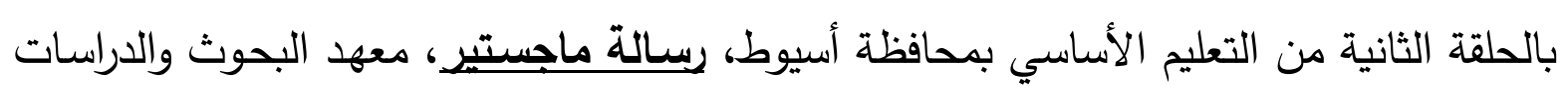

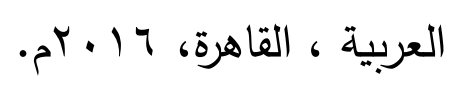

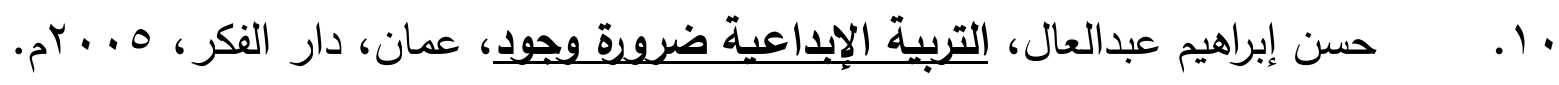

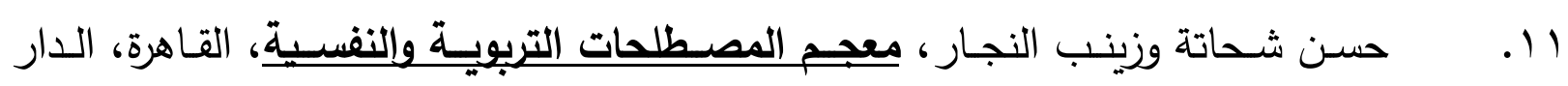

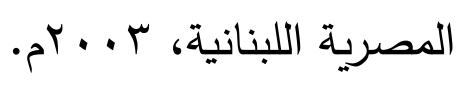

r ا. حسين رشوان، الأسس النفسية والاجتماعيـة للابتكلـ، الإنكندرية، الدكتب الجامعي الحديث، r.. Trم. 
r ا. حسين رشوان، الأسسس النفسية والاجتماعيـة للابتكـار، الإسكندرية، المكتب الجامعي

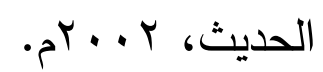

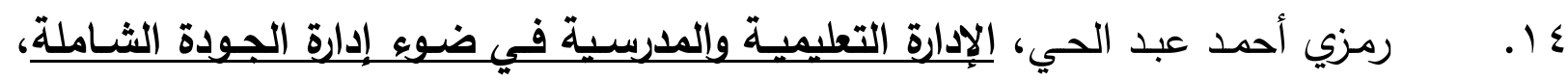

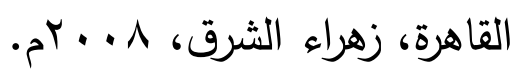

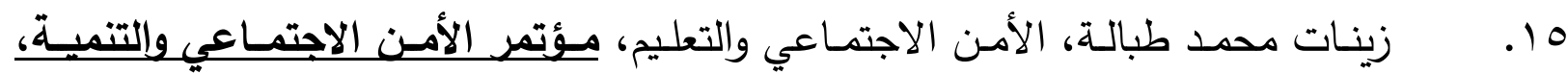

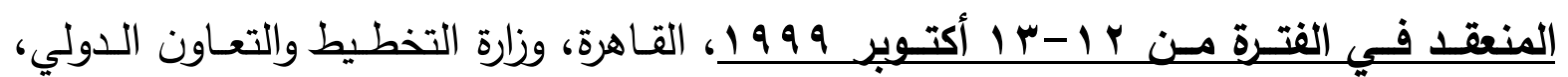

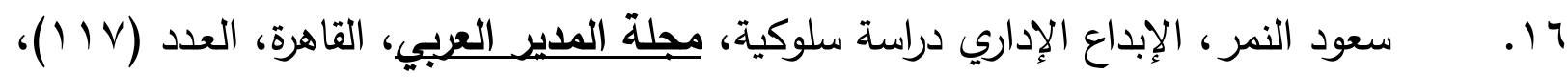
. $) 99 r$

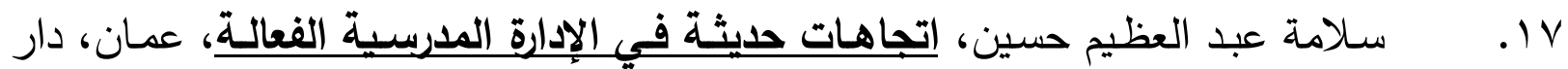

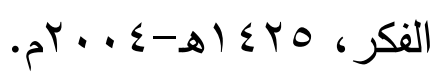

11. صالح أحمد عايد البلوي، تطوير إدارة الجامعات الناشئة بالمملكة العربية السعودية في

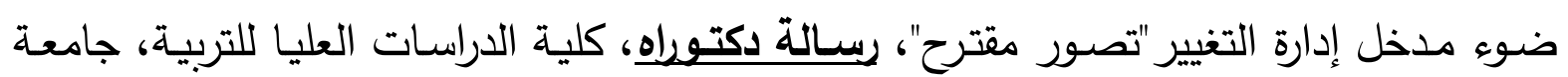

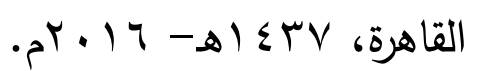

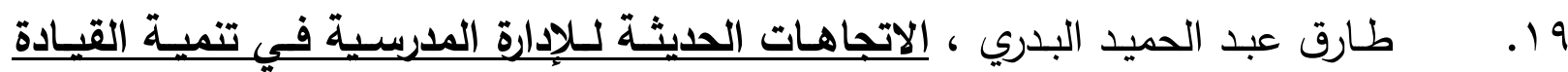

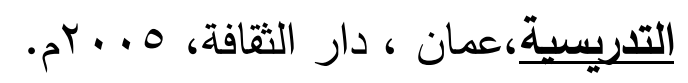

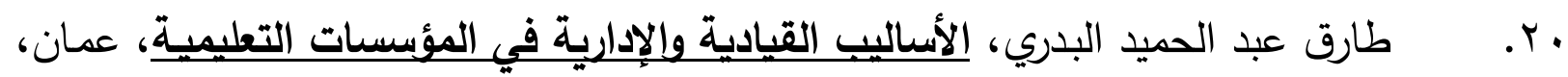

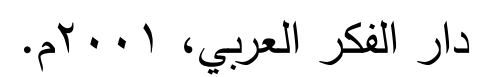

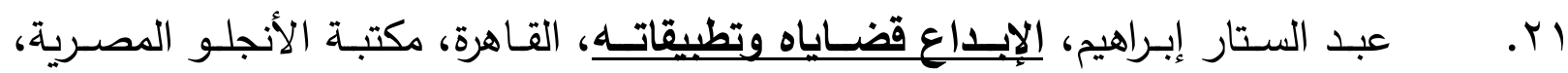

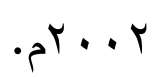

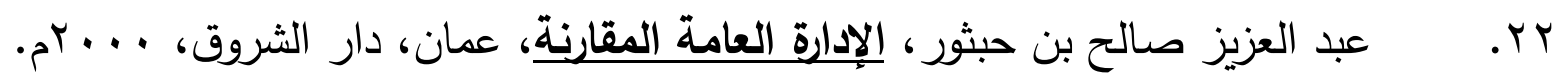

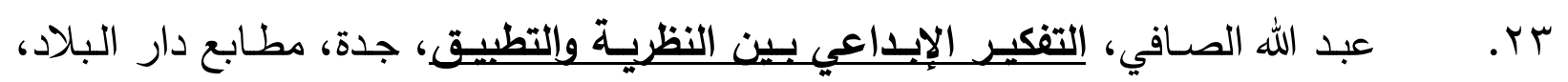
. $) 99 \mathrm{~V}$

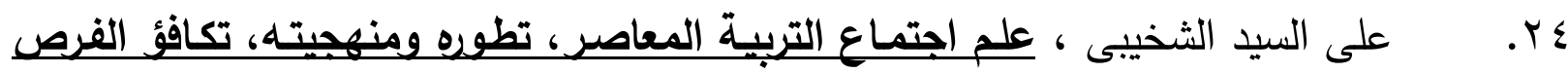

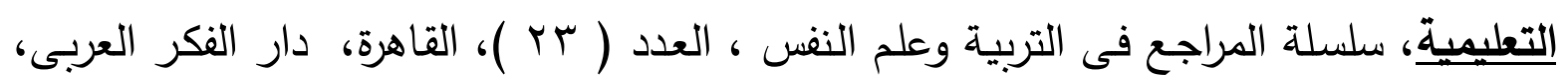
$\cdot r+r$

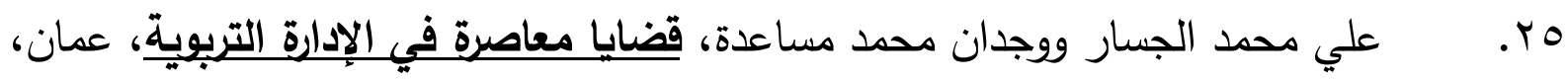

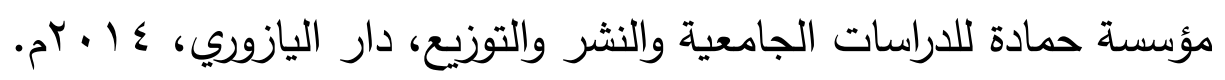


דr. عمر إبراهيم حامد إبراهيم، تطوير الممارسات الإداريـة لمديري المدارس الثانويـة العامة بمصر على ضـوء مدخل الإدارة بالقيم،رسـالة دكتوراه، كلية البنات لـلاداب والعلوم والتربيـة،

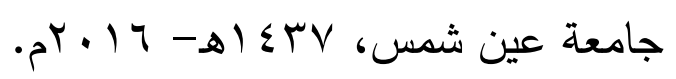

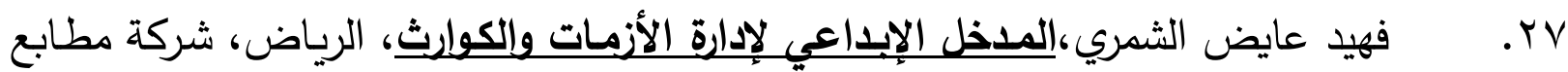

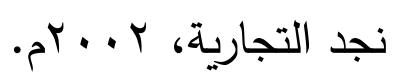

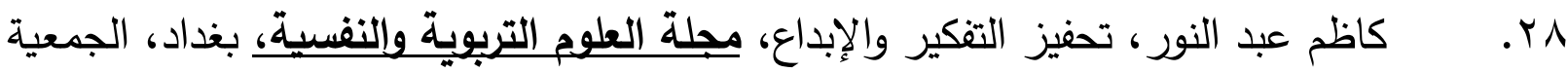
العراقية للعلوم التربوية والنفسية، 991 ام.

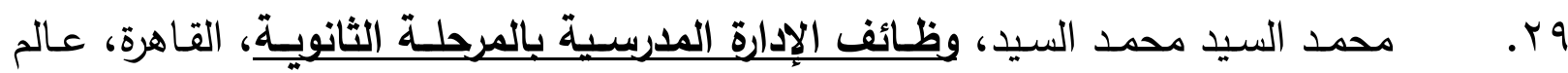

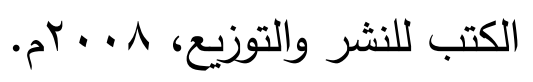

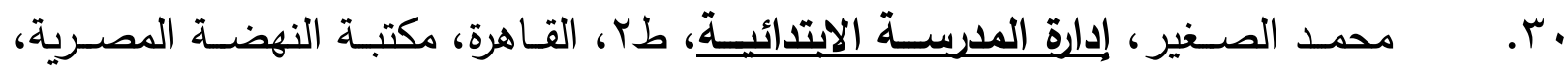
.

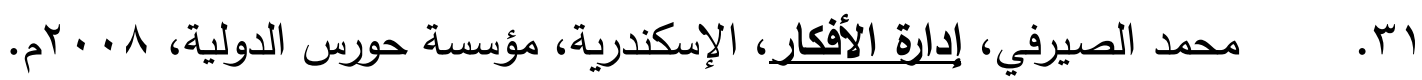

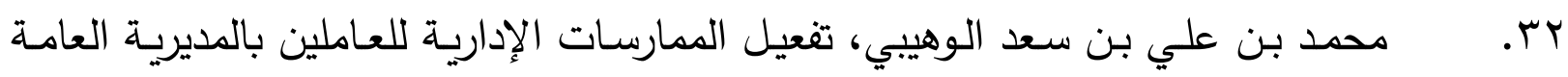

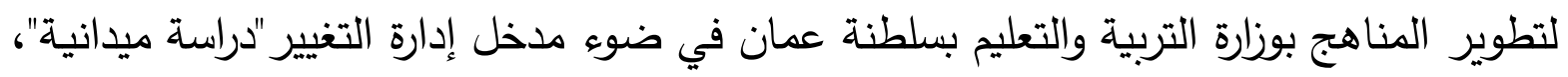
رسالة ماجستير، كلية التربية، جامعة السلطان قابوس، سلطنة عمان، 9 . . بم.

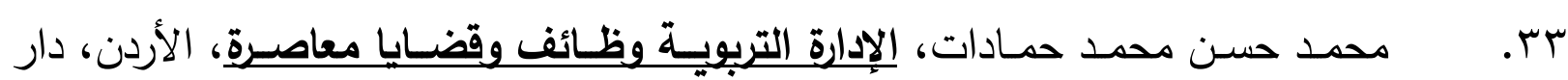

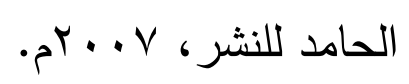

گ ז. مددوح عبد المنعم الكناني، سيكولوجية الإبداع والتجديد لدى الأفراد والمنظمات، القاهرة،

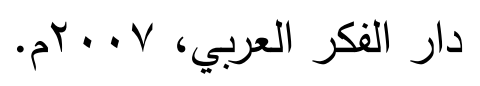

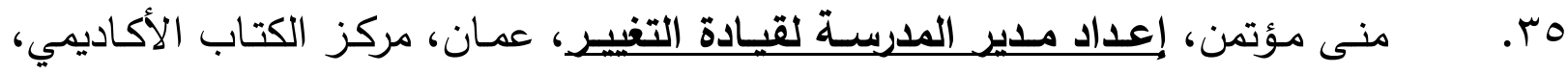

$$
\text { . }
$$

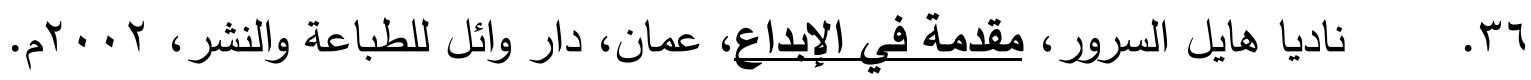

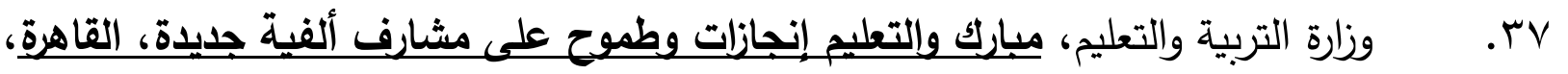

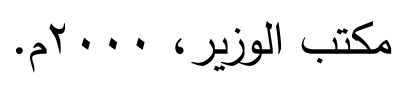




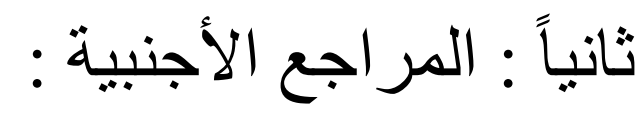

38. Alanezi, A., The relationship between shared leadership and administrative creativity in Kuwaiti schools, Management in Education Journal, Vol.30, No.2, 2016.

39. Al-Oweidi, A., Creative Characteristics and its Realism to Achievement and School Type among Jordanian Students, Creative Education, Vol.4, No.1, 2013.

40. Brogmenke, A., Avoiding the change trap: Strategies for school leaders in times of change. Texas: National Forum of Educational Administration and Supervision Journal, Vol.29, No.2, 2012.

41. Brookly, Foster, A School culture Of Innovation And Creativity, Minnesota: The University of Minnesota, 2001.

42. Carter McNamara, Basic Context for organizational change. PhD, Retrievedfromhttps://managementhelp.org/organizationalchange/basics.h tm On 23/6/2018

43. Daft Richard L.\&Noe Raymond A, Organizational Behaviour, New York, America, Harcourt College Publishers, 2001.

44. Gilsen, C., The readiness levels of secondary school administrators to the innovation management, International Journal on New Trends in Education and Their Implications, Vol.5, No.2, 2014. 45. Harvey, D \& Brown, D, An Experiential Approach to Organization Development, $7^{\text {th }}$ Ed, Prentice Hall, 2006. 46. Kotter, J., Leading Change: Why Transformational Efforts Fail, Harvard Business Review Press, 1995.

47. Lodico, M. \& et al: Methods in Educational Research; From Theory to practice, Jossey-Bass, London, 2006, p104.

48. Pattanayak, B. \& Mishra, P.K, Change for Growth: Understanding Organizational Development, New Delhi, Wheeler publishing, 2009. 
49. Soleimani, N., \& Tebyanian, E., A study of the relationship between principal's creativity and degree of environmental happiness in Semnan high schools, Procedia - Social and behavioral Sciences 29 , 2011.

50. Zabelina, D \& Robinson, M., Creativity as Flexible Cognitive Control, Psychology of Aesthetics, Creativity, and the Arts, Vol.4, No.3, 2010. 